\title{
The Role of Government Measures in University-Industry Collaboration for Economic Growth: A Comparative Study across Levels of Economic Development
}

\author{
Ewa Kopczynska | ORCID: 0000-0002-9344-529X \\ University of Beira Interior \& NECE - Research Unit in Business Sciences, \\ Covilhã, Portugal \\ ewa@ed-knowledgeconsulting.com \\ Joao J. Ferreira | ORCID: 0000-0002-5928-2474 \\ University of Beira Interior \& NECE - Research Unit in Business Sciences, \\ Covilhã, Portugal
}

\begin{abstract}
Nowadays, countries across the world aspire to increase their innovation for the common good. In this scope, and among others, the Triple Helix thesis emphasizes the role of collaboration between stakeholders from academia, industry and government to bring about effective innovation. Despite efforts to encourage university-industry (U-I) collaboration, bridging U-I barriers remains among the relevant economic and policy challenges. Among other aspects, it has been argued that the tendency to transfer tools from developed to underdeveloped countries hinders the capacity to obtain the full potential of U-I collaboration. As no empirical study validating such hypothesis has been identified, our study tests $\mathrm{i} /$ whether U-I collaboration has a different impact on growth depending on the level of economic development, ii/ whether the impacts of specific governmental measures on U-I collaboration differ at different levels of economic development. Our findings suggest that up till now the potential of U-I collaboration remains underutilized across all levels of development. Our results show that diversified policy measures are relevant at different development levels. Furthermore, their relevance may also evolve over time. However, such factors as quality of research institutions and private $R \& D$ investments are critical across development levels and time.
\end{abstract}




\section{Keywords}

economic development - open innovation - policy measures - university-industry collaboration

\section{Arabic}

$$
\begin{aligned}
& \text { دور الإجراءات الحكومية في } \\
& \text { التعاون بين الجامعة والصناعة في المجال الاقتصادي }
\end{aligned}
$$

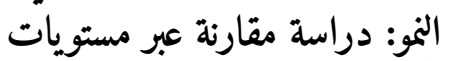

$$
\begin{aligned}
& \text { المنو الإقتصادي }
\end{aligned}
$$

\section{الملخص}

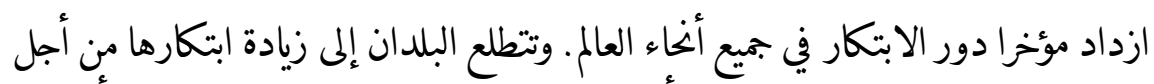

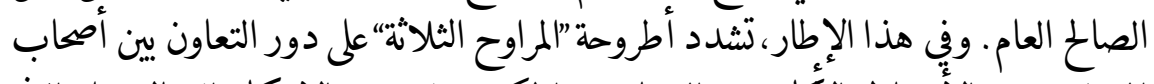

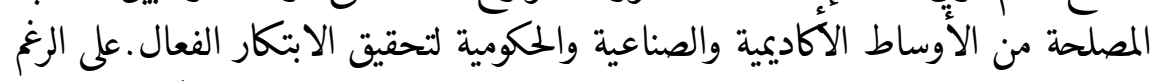

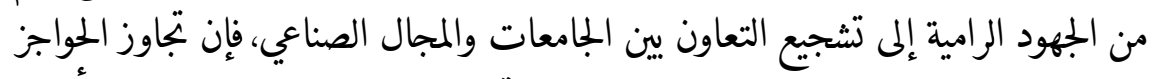

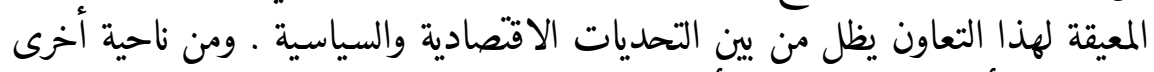

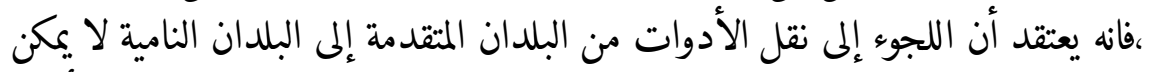

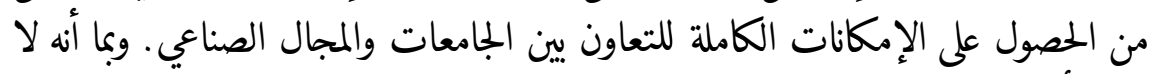

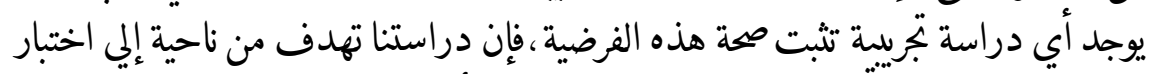

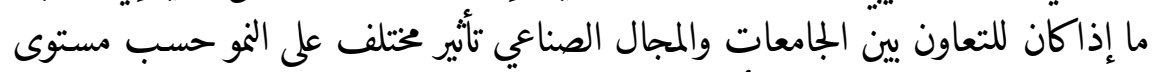

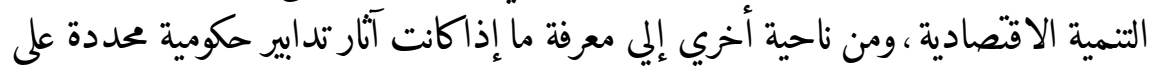

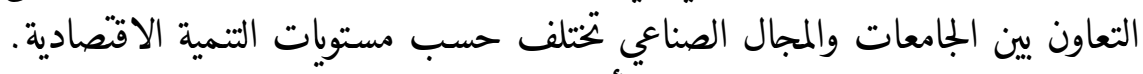

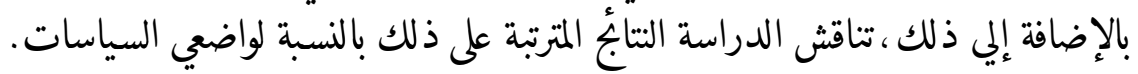

\section{الكلمات المفتاحية}

التمية الاقتصادية ؛الابتكار المفتوح ؛ تدابير السياسات ؛ التعاون يين الجامعة والمجال الصناعي 


\title{
Chinese
}

\section{政府措施在产学合作促进经济增长中的作用:跨经 济发展水平的比较研究}

\author{
Ewa Kopczynska and Joao J. Ferreira
}

摘要

最近, 创新的作用在世界各地都有所增加。各国渴望为了共同利益而增加创新。在 这个领域, 三螺旋理论强调学术界、工业界和政府的利益相矢者之间的合作在促进 有效创新过程中的作用。尽管政策鼓励大学与产业(校企) 的合作, 但克服校企合作 中的障碍仍然是相矢的经济和政策挑战之一。在其他领域的研究, 有观点指出将政 策工具从发达国家转移到欠发达国家的趋势, 阻碍了充分发挥 校企合作潜力的能 力。由于尚没有验证该假设的实证研究, 我们的研究测试了:1) 校企合作在创新中 的作用, 是否会因区域经济发展水平的差异而产生不同影响, 2) 特定的政府措施 对校企合作的影响, 是否会在不同经济发展水平的地区有不同的表现。此外, 该文 还讨论了研究结果对决策者的启示。

\section{关键词}

经济发展 - 开放创新 - 政策措施 - 产学研合作 


\title{
French
}

\section{Le rôle des mesures gouvernementales dans la collaboration université-industrie pour la croissance économique : une étude comparative à travers les niveaux de développement économique}

\author{
Ewa Kopczynska and Joao J. Ferreira
}

\section{Résumé}

Le rôle de l'innovation s'est récemment accru dans le monde entier. Les pays aspirent à accroître leur innovation pour le bien commun. Dans ce cadre, et entre autres, la thèse Triple Hélice met l'accent sur le rôle de la collaboration entre les parties prenantes de l'université, de l'industrie et du gouvernement pour apporter une innovation efficace. Malgré les efforts visant à encourager la collaboration Université-Industrie (U-I), surmonter les obstacles U-I reste l'un des défis économiques et politiques pertinents. Entre autres aspects, il a été avancé que la tendance à transférer les outils des pays développés vers les pays sous-développés entrave la capacité d'obtenir le plein potentiel de la collaboration U-I. Comme aucune étude empirique validant une telle hypothèse n'a été identifiée, notre étude teste 1/ si la collaboration Université-Industrie a un impact différent sur la croissance selon le niveau de développement économique, 2 / si les impacts de mesures gouvernementales spécifiques sur la collaboration Université-Industrie diffèrent à différents niveaux de développement économique. En outre, elle examine les conséquences de ces résultats pour les décideurs politiques.

\section{Mots clés}

développement économique - innovation ouverte - mesures politiques - collaboration université-industrie 


\title{
Portuguese
}

\section{O papel das medidas governamentais na colaboração universidade-indústria para o crescimento econômico: um estudo comparativo entre os níveis de desenvolvimento econômico}

\author{
Ewa Kopczynska and João J. Ferreira
}

\begin{abstract}
Resumo
O papel da inovação aumentou recentemente em todo o mundo. Os países aspiram a aumentar sua inovação para o bem comum. Nesse escopo, e entre outros, a tese da Triple Helix enfatiza o papel da colaboração entre as partes interessadas da academia, indústria e governo para gerar inovação efetiva. Apesar dos esforços para encorajar a colaboração universidade-indústria (U-I), superar as barreiras do U-I permanece entre os desafios econômicos e políticos relevantes. Entre outros aspectos, argumentou-se que a tendência de transferência de ferramentas de países desenvolvidos para países subdesenvolvidos dificulta a capacidade de obter todo o potencial da colaboração U-I. Como nenhum estudo empírico que valida tal hipótese foi identificado, nosso estudo testa 1 / se a colaboração da IU tem um impacto diferente no crescimento dependendo do nível de desenvolvimento econômico, 2 / se os impactos de medidas governamentais específicas sobre a colaboração da IU diferem em diferentes níveis de desenvolvimento Econômico. Além disso, discute as consequências das descobertas para os decidores políticos.
\end{abstract}

\section{Palavras-chave}

desenvolvimento econômico - inovação aberta - medidas políticas - colaboração universidade-indústria 


\title{
Russian
}

\section{Роль государственньх требований к сотрудничеству университетов и промышленности в обеспечении экономического роста: сравнительный анализ с учетом уровней экономического развития}

\author{
Э.Копиинска, Дж.Дж. Ферейра
}

\begin{abstract}
Аннотация
Роль инноваций значительно возросла во всем мире. Страны рассчитывают на увеличение доли инноваций в традиционных продуктах. В этом и многих других контекстах, Тройная спираль делает акцент на роли сотрудничества между представителями университетов, промышленности и государства в создании эффективных инноваций. Несмотря на инициативы по расширению сотрудничества между университетом и промышленностью (U-I), барьеры между спиралями U-I создают значительные экономические и политические вызовы. Среди прочего известно о том, что трансфер технологий из развитых в развивающиеся страны мешает раскрытию полного потенциала от сотрудничества U-I. Поскольку эмпирические исследования по данной тематике отсутствуют, наша работа посвящена изучению 1) влияния сотрудничества U-I на динамику роста в зависимости от уровня экономического развития 2) влияния специфических государственных мер в отношении сотрудничества U-I и их различий в зависимости от уровня экономического развития. Далее, в статье обсуждаются результаты исследования применительно к государственным стратегиям.
\end{abstract}

\section{Ключевые слова}

Экономическое развитие - Открытые инновации - Требования к стратегиям Сотрудничество университет-промышленность 


\title{
Spanish
}

\section{El papel de las medidas gobiernamentales en la colaboración universidad-industria para el crecimiento económico: un estudio comparativo entre niveles de desarrollo económico}

\author{
Ewa Kopczynska and Joao J. Ferreira
}

\section{Resumen}

El papel de la innovación ha aumentado recientemente en todo el mundo. Los países aspiran a incrementar su innovación para el bien común. En este ámbito, y entre otros, la tesis de la Triple Hélice enfatiza el papel de la colaboración entre los actores de la academia, la industria y el gobierno para lograr una innovación efectiva. A pesar de los esfuerzos para fomentar la colaboración universidad-industria (U-I), superar las barreras U-I sigue siendo uno de los desafíos económicos y políticos relevantes. Entre otros aspectos, se ha argumentado que la tendencia a transferir herramientas de países desarrollados a países subdesarrollados dificulta la capacidad de obtener todo el potencial de la colaboración U-I. Como no se ha identificado ningún estudio empírico que valide tal hipótesis, nuestro estudio prueba 1 / si la colaboración de Ui tiene un impacto diferente en el crecimiento dependiendo del nivel de desarrollo económico, 2 / si los impactos de medidas gobiernamentales específicas sobre la colaboración de UI difieren en diferentes niveles de desarrollo economico. Además, analiza las consecuencias de los resultados para los decidores políticos.

\section{Palabras clave}

desarrollo económico - innovación abierta - medidas políticas - colaboración universidad-industria 


\section{Introduction}

The overall level of innovation within an economy is an outcome of the performance of both the academic and industrial sectors. Their crucial role as providers of knowledge and innovation makes national and regional innovativeness and competitiveness strongly dependent on their performance as well as on the Triple Helix interactions (Cowan and Zinoryeva 2013; Mark et al. 2014; Martins, 2016). In addition, there is general acceptance that universityindustry collaboration provides positive impacts on economic development (Hou et al. 2021). This underpins the calls for government to embrace supportive roles in fostering university-industry (U-I) collaboration within the scope of innovation. Calls for building strong Triple Helix relationships that enable the optimal capitalisation of the national knowledge resources and their efficient transformation into economic and social gains stem from both the academic literature and policymaker-oriented reports (Welch et al. 2008; Wonglimpiyarat and Khaemasunun 2015; OECD 2019). Lowering barriers to U-I collaboration, stimulating collaborative innovation, and creating a proper innovation environment feature among the challenges commonly ascribed to governmental actors (Ranga et al. 2008; Chen et al., 2013; Runiewicz-Wardyn 2014). Following this general consensus, funding schemes for collaboration, creating umbrella organisations or specific infrastructures (i.e., science and technology parks) became widespread strategies for stimulating U-I collaboration and its contribution to economic development (Cooke, 2002; Peng et al., 2017). However, to generate the positive economic and social impacts of such efforts, decision-makers need a clear understanding of their expected impacts in specific contexts. Furthermore, they require evidence-based justification for continuing interventions in this area (Mark et al. 2014). These needs fuel the current growth in research regarding the efficiency and effectiveness of collaborative innovation. Despite the universal need for better policies and information regarding the innovation environment, the research still strongly focuses on a specific geographic context, mostly within developed counties, especially the USA and European states (Mowery and Sampat 2004; Mark et al. 2014; Galan-Muros and Plewa 2016, Nsanzumuhire and Groot 2020). Such a focus often guides decision makers toward transferring the well-established and successful models highlighted in the literature to their often significantly different national contexts (Mowery and Sampat 2004). Due to different economic, institutional and sociocultural factors, such naive transfers of measures between different contexts may turn out inefficient or unsuccessful (Salem and Amjed 2008; Ankrah and Omar 2015; Teller and Validova 2015; Havas 2015). In particular, differences in levels of development often emerge as a factor of high 
relevance for the effective translation of investment in supporting U-I collaboration into socioeconomic benefits (Amaral et al., 2011; Cowan and Zinoryeva, 2013; Hou et al., 2021). These differences in development may also impact on the relevance and roles of governments and universities within the innovation ecosystem and specifically within the Triple Helix model (Macleod et al., 1997; Rad et al., 2015; Ankrah and Omar, 2015; Kim and Jang, 2021). Among others, Ankrah and Omar (2015) underline that while the critical role of government has received empirical confirmation in the case of developed economies, such postulated effects for emerging and developing countries still need further research. On the other hand, Hou et al. 2021 report that while in China government funding significantly promotes U-I research efficiency, the effect has been contrary in developed countries. While the body of knowledge regarding U-I collaboration is growing rapidly, there remain relevant gaps regarding understanding the impacts of measures and specific strategies that might effectively guide the direction of future reforms (Nsanzumuhire and Groot 2020; Hou et al. 2021). Alongside other facets, to the best of our knowledge there is a specific lack of cross-country comparative studies that might provide insights into the often ambiguous assessments of the effects of U-I collaboration in different economic conditions. To overcome this gap, our study seeks to approach this issue through a macro level comparative study. Based on regression analysis, the study tests $1 /$ whether the U-I collaboration effect on economic development differs depending on the national level of development, and 2/ whether the enabling character of macro-level strategies for U-I collaboration differs between countries at different development levels. Hence, we aim to verify whether U-I collaboration might provide stronger stimuli to economic growth in lesser developed countries and whether the potential of specific policy-related factors and measures to stimulate U-I collaboration differs among countries at different stages of development.

In opposition to our expectations and to the already confirmed differences in the effect of knowledge-spill-overs on economic development at the regional level (Cowan and Zinoryeva, 2013), our quantitative analysis reported no evidence of different impacts of U-I collaboration on economic development within this cross-country analysis. Altogether, our study findings report no significant positive relationship between U-I collaboration and economic development. This may suggest that, despite strong attention to U-I collaboration in developed countries, economies across every level of development have not yet reached the critical mass or the level of U-I collaboration effectiveness able to drive results with significantly positive effects on economic development. This correspondingly indicates that, at the macro-level, U-I collaboration may provide indirect impacts on economic development through 
enhancing the innovativeness and competitiveness of companies (Berman 1990; Mark et al. 2014) but only more effective U-I collaboration strategies would be able to generate significant boosts to economic development at the macro-level. This reflects the critical need for a better understanding of the effectiveness of specific policy strategies and instruments and for a stronger focus on supporting the effectiveness rather than the volume of U-I collaboration within the framework of innovation.

In accordance with these needs, our study of the impact of specific measures confirms that specific policy mixes should take into account the level of development. Furthermore, specific policy strategies should be flexible and periodically revised. Such an approach is especially relevant in countries at the lowest levels of development. Some factors, such as the quality of the research institutions and private $R \& D$ investments, demonstrate the relevant role for U-I collaboration across every level of development. Meanwhile, staff training, access to financing and institutional factors hold relevance at different development levels. Our results thereby demonstrate not only how the influence of specific measures differs significantly between different development levels but also that the relevance of specific measures for stimulating U-I collaboration depends on the respective level of development. The study then discusses the policy implications of these findings and underlines the specific need to make adjustments to current policy strategies.

Following this introductory section comes the theoretical framework and methodology sections. Section 4 presents the data analysis process and the results obtained, which are subject to further discussion in section 5 . The article is finalised with conclusions summarising the key takeaways, study limitations and future research directions.

\section{Background and Theoretical Framework Review}

The fast pace of technological change at the close of the 2oth century, shifted beliefs regarding the drivers of economic growth. The New Growth Theory postulates that driving the growth rate are factors such as the effective usage of human capital, innovation and investment capital rather than it is stemming from a direct outcome of external uncontrollable forces as postulated by preceding economic growth theories. This switched the key focus from traditional physical resources to the stock of knowledge and to the specific ability to produce, identify and exploit that knowledge within an economic system (Romer 1990). This therefore highlights the relevance of the country's innovation capacity, its ability - as both a political and economic entity - to produce 
and commercialise flows of new-to-the-world technologies over the long term (Furman et al. 2002) in order to sustain macro level economic growth. Furthermore, New Growth Theory and the innovation capacity theory placed policy-dependant factors, such as public innovation infrastructure, innovative environment and the strength and effectiveness of ecosystem linkages, at the core of modern strategies for sustainable economic growth while also underlining the relevance of supporting linkages between knowledge and innovation actors (Romer 199o; Furman et al. 2002). More recently, the Triple Helix thesis specifically points out the linkages between university and industry as critical assets for innovation performance, calling for a strategic alliance between university, industry and government for knowledge-based economic development in which governments should provide and manage the supportive framework (Etzkowitz and Leydesdorff 200o). The existence of such collaboration is associated with the increased competitiveness of the participant organisations, potential positive impacts on the quality of life by enhancing both the pool of available innovation and the quality of information and knowledge available and with general agreement over the positive impacts on regional and national economic development (Howarth and Monasterolo 2016; Hou et al. 2021).

In recognition of the relevance of U-I collaboration to competitiveness, government strategies across the globe involve implementing support for U-I collaboration (Etzkowitz and Leydesdorff 2000; Mark et al. 2014). The most commonly implemented policies involve the following facets (Alshehri et al. 2016; Peng et al. 2017; OECD 2019):

Schemes and incentives to support U-I collaboration;

U-I relationship enabling legal frameworks;

Establishing research centers and/or service providers to facilitate U-I collaboration;

Providing support for clusters, science and technology parks (STPs), innovation centers and business incubator infrastructures.

Furthermore, some countries adopted U-I collaboration as a strategic priority. Among others, in 1994 China was already instructing all universities and research centres to prioritise services to industry before, in 2005, making U-I cooperation a national strategy (Peng et al. 2017). Meanwhile, others perceive U-I collaboration as an integral part of their innovation or open innovation strategies, i.e. Austria with one of the first national open innovation strategies aiming at broad reaching collaboration between industry, science, public administration and society (BMWFW, 2015). Despite the common recognition of the importance of U-I collaboration, the current body of literature suggests 
the progress in the level and quality of U-I collaboration in terms of innovation on a global scale displays limitations and is generally unsatisfactory. This includes those countries with strong focuses on specific support policies for this area (Rad et al. 2015; Peng et al. 2017; Hou et al. 2021). Such a situation raises certain doubts as regards the significance of governmental engagement, the appropriate application of current measures and the need to better understand the existing models and their impact. Researchers often underline how such effects may stem from the gaps in innovative capacity and the general lack of consideration for the socioeconomic factors impacting on U-I relationships (Teller and Validova 2015). However, the current body of literature often overlooks how NIS research highlights how innovation and technological change constitute the main factors for competitiveness and economic growth specifically in developed countries (Freeman 1982, 1987; Nelson 1990). This correspondingly also broadly ignores how NIS research findings suggest the need for launching specific frameworks for improving innovation performance in less developed countries rather than transferring strategies from developed economies (Lundvall 2007; Watkins et al. 2015). Researchers thus does not always take into account how, according to the stages of development theory, different factors drive economic competitiveness and economic growth at different levels of development and any particular development phase commonly interrelates with different capacities and impacts of the measures required for effectively engaging actors in modernisation and innovation processes (Rostow 1962).

\section{The Government Role in U-I Collaboration}

The current body of literature on U-I collaboration postulates far reaching benefits from U-I collaboration for economies. The literature links U-I collaboration and knowledge transfer with national prosperity and intellectual capital (Salem and Amjed, 2008), proposing a positive impact on economic growth through directly contributing to competitiveness and indirectly by improving the efficiency of resource exploitation and increasing the innovativeness and capabilities of industry (Berman 1990; Mueller 2006; Mark et al. 2014).

However, due to a broad range of barriers, U-I collaboration commonly encounters obstacles (Gera 2012). While the need for a supportive governmental role gains general recognition, authors differ in their stances as regards the actual ability of governments to impact on the level and efficiency of U-I collaboration. Some authors directly accredit the government with the mission of fostering and coordinating U-I relations (Lee and Yoo 2007; Rad et al. 2015). 
Others postulate a supportive character for governments interrelated with coordination of the National Innovation System. The latter propose that U-I collaboration should rather be facilitated intrinsically due to, among other factors, the low level awareness among governmental agencies about the business environment and its needs (Langford et al. 1997; Etzkowitz and Leydesdorff, 2000; Lee and Yoo, 2007; Suomi et al. 2019).

While the optimal role of government in U-I collaboration remains unclear, research findings rather consistently point to governments holding an enabling role in U-I collaboration. Researchers especially emphasise the relevance of the political will to improve U-I collaborative environments, the design of intelligent strategies, frameworks and mechanisms and fostering collaborative culture as key factors of success to enhance U-I collaboration within the framework of innovation (Salem and Amjed 2008; Sandberg et al. 2015; Rad et al. 2015; BMWFW, 2015). Government efforts to nurture U-I collaboration may significantly bridge U-I collaboration gaps by, on the one hand, providing political encouragement for companies (Al-Agtash and Al-Fahoum, 2008) and, on the other, impacting on university policies and providing external incentives for universities to engage in U-I collaboration within the scope of innovation (Welsh et al. 2008; Rad et al. 2015). Unfortunately, despite the common application of policy measures supporting U-I collaboration across the globe, the specific university-industry-government dynamics are still only poorly theorized and clear guidance for decision-makers is still lacking (Ankrah and Omar 2015; Sandberg et al. 2015; Kim and Jang 2021; OECD 2019). The current state of knowledge suggests that maximising the public benefits of knowledge by enhancing U-I collaboration requires the creation of strongly articulated and clearly defined policies protecting the intellectual property and trade secrets of firms on the one hand, and the autonomy and freedom of operation and communication of university scientists on the other (Welsh et al. 2008; Sandberg et al. 2015; Alshehri et al. 2016; OECD 2019). Policies should cultivate an environment fostering communication and open innovation between various entities (BMWFW 2015: Alshehri et al. 2016; Peng et al. 2017). Within this scope, the government should specifically focus on bridging the organisational barriers and facilitate win-win U-I relationships. Among other aspects, there is a general consensus around the strong mandate of governments to bridge discrepancies in U-I incentives. However, challenges related with cultural goals and knowledge gaps also need consideration (Sandberg et al. 2015; Kim and Jang 2021). Additionally, with increasing globalisation, regions and nations need to create an organisational framework that will allow agents to be both local and global players while ensuring the distribution of the wealth generated by knowledge in the region (Leydesdorff et al. 2014). 
While underlining the multiple challenges for policy-makers, the existing body of literature in practical terms does not propose any thorough literature and current policy recommendations are commonly very generic (Mark et al. 2014; Ankreh and Omar 2015; Hou et al. 2021). That gap stems from i/ the deep complexity of the issues around the policy mix and its relationship to specific conditions, ii/ the tendency to study policy instruments only in isolation or in specific geographic contexts and, iii/ limited data regarding U-I collaboration and the efficiency of specific policies (OECD 2019). Empirical studies focused on policy analysis and case studies furthermore indicate that policies may result in different outcomes depending on differences in the development level or even within the same development group. This may result from the prevailing market characteristics and differences in industrial contexts (Lee and Yoo 2007; Salem and Amjed 2008; Kim and Jang 2021; Hou et al. 2021). The US biotechnology industry represents one of the most successful examples of the policy framework impact on U-I collaboration. In this case, declines in public funding for university research in conjunction with legislation promoting U-I collaboration pushed universities to actively engage in market activities. This resulted in new techniques and products and the biotechnology sector making a greater economic contribution to the US economy (Welsh et al. 2008). However, studies of less developed countries suggest that any transfer of such measures will not lead to similar results. Due to stronger barriers, such as the capital limitations of industry lacking the resources to finance industry-oriented $R \& D$ at universities or a lack of sufficient knowledge and absorptive capacity, the anticipated impacts of such policy measures therefore differ (Mueller 2006; Rad et al. 2015). Under such conditions, some researchers accredit the key role in stimulating U-I collaboration, and industrial development itself, to universities rather than to government. Meanwhile, they also underline the government mandate to $\mathrm{i} /$ increase incentives for universities to engage in such missions by rewarding their efforts and contributions to efficient U-I collaboration, ii/ mediate the lack of trust on the side of companies and, iii/ broaden the freedom of universities to cooperate with firms (Yuthavong et al. 1993; MacLead et al., 1997; Rad et al. 2015; Hou et al. 2021). As we may conclude from the aforementioned literature, there is a general understanding that specific policy measures to encourage effective innovation focused U-I collaboration require an intelligent design tailored to the specific U-I context. Furthermore, it is crucial to develop institutional environments with political and social systems that enable rather than obstruct interactions between different innovation actors (Hassen 2018; Kim and Jang, 2021; OECD 2019).

However, studies seeking to define how such policies impact on U-I collaboration and interactions depending on the specific conditions of their 
application are scarce. Among the rare cross-country approaches, the recent OECD report regarding U-I collaboration analyses policies supporting knowledge transfers across OECD countries. This underlines how macroeconomic conditions, as well as differences in maturity of science-technology linkages, need taking into consideration when designing an intelligent policy framework for supporting U-I collaboration (OECD 2O19). However, this nevertheless does not provide any specific indications about which the different measures return which impacts and effects. Therefore, in order to contribute to generating more direct indications for policy-makers alongside a better understanding of the impact of different instruments on U-I collaboration, this study seeks to better grasp how different levels of development influence the need for different approaches to supporting U-I collaboration. Following the existing indications that economies at different development levels require specific policy frameworks for U-I collaboration in the scope of innovation (Lundvall 2007; Watkins et al. 2015; Rad et al. 2015; Hou et al. 2021) and that the development level constitutes one of the main differentiators that needs accounting for within the analysis of university-industry relations (Nsanzumuhire and Groot 2020; Hou et al. 2021), we hereby postulate that:

$\mathrm{H}_{1}$ - the positive influence of policy interventions on U-I collaboration differs between countries at different development levels.

The existing literature describes how among the differences existing between development levels, the main policy concerns of developed countries related to U-I collaboration interlink with intellectual property rights, issues related to researcher conflicts of interest and the pressures on scientific communication (Welsh et al. 2008; Suomi et al. 2019). On the other hand, the common concentration of the knowledge pool within academia, leading to extensive gaps between university and industry in the culture, knowledge and absorptive capacities represent the main issues requiring attention in lesser developed regions. Meanwhile, the importance of issues such as intellectual property rights is highly limited in such regions (Macleod et al. 1997; Mueller 2006; Rad et al. 2015; Cassanelli et al. 2017). Some issues, such as macro-level pressure on publishing, amount to global problems. However, countries at different development levels exhibit different needs for U-I collaboration mechanisms as well as different potentials for U-I collaboration to translate into economic and social impacts (Macleod et al. 1997; Ankrah and Omar 2015; Kim and Jang 2021; Nsanzumuhire and Groot 2020).

When we consider how low development levels interrelate with limited stocks of knowledge and poor innovative capacities within industry, the limited spill-overs of academic knowledge may drive sharp restrictions on the 
size and competitiveness of industries and, therefore, the overall economy (Mueller 2006; Cowan and Zinoryeva 2013; Pablo-Hernando 2015; Suomi et al. 2019). On the other hand, a study of Italian regions demonstrates how poor regions with relatively low innovative capacities benefit the most from the location of universities in their territories (Cowan and Zinoryeva 2013). The findings empirically convey how economic disparities potentially generate strong impacts on the relevance of U-I collaboration for the region or country. Especially due to the increase in the complexity of knowledge and the increased role of knowledge for competitiveness, the importance of circulating academic knowledge in economic environments and ensuring crossorganisational co-production of knowledge increases (Suomi et al. 2019). This implies that, in the current global market, the effective engagement of universities with industry and enabling the availability of modern market-oriented knowledge and its assimilation within industry may have stronger impacts on stimulating the growth of companies and economies in less developed locations. In such cases, customised adjustments in governance and the evolution of economic systems emerge as especially significant for overcoming the development disparities in lagging countries (Petroni et al. 2012; Martins 2016). Positive effects may arise from transfers of knowledge, encouraging entrepreneurship or providing university resources to industry. As the hypothesis of such differences has not previously been subject to analysis from a comparative perspective, our study aims to test that proposition:

$\mathrm{H}_{2}$ - the U-I collaboration will stimulate stronger economic growth in less developed countries.

Therefore, our research model firstly seeks to verify whether U-I collaboration provides stronger stimuli to economic growth in less developing countries and whether the potential returns from specific policy-related factors and measures for stimulating U-I collaboration differ in countries at different stages of development (see Figure 1).

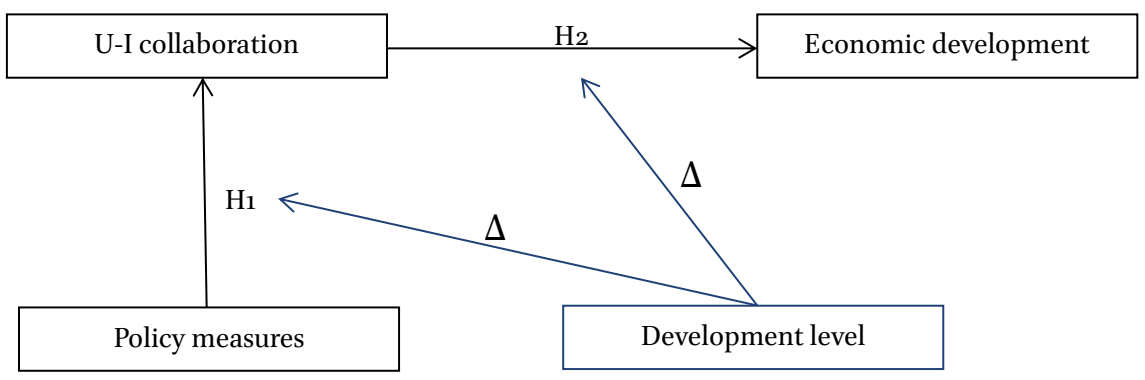

FIGURE 1 Research model 


\section{Methodology}

\section{Models and Method}

Our research model focuses on two independent hypotheses. We therefore seek to understand the dependencies between a number of predictors and a single metric dependant variable in both cases. We specifically aim to verify the hypothesis postulated based on independent models of $1 /$ economic growth (within the scope of $\mathrm{H}_{2}$ ) and 2/ U-I collaboration at the macro level (within the scope of $\mathrm{H1}$ ). In accordance with the research objectives and the research model established, we applied multivariate regression to evaluate the impact of the dependant variables and the diversification of impacts across different development groups based on the applicability of the method in line with the research model and the specific variables analysed as postulated in the literature (Hair et al. 2010).

To analyse the hypothesised causal relationship between U-I collaboration and economic growth, in accordance with the existing literature, the proposed economic growth model (Simionescu et al. 2017) assumes a function of U-I collaboration (Plewa et al. 2013; Ambroziak et al. 2016; Simionescu et al. 2017); financial factors (Fischer 1993; Simionescu et al. 2017); entrepreneurship (van Stel et al. 2005; Gonzalez-Pernia and Pena-Legazkue 2015) and innovation (Gonzalez-Pernia and Pena-Legazkue 2015). In the case of the U-I collaboration model, this expect the perceived U-I collaboration to be dependent on policies related to $\mathrm{i} /$ the pool of knowledge, skills and absorptive capacity of stakeholders (Pablo-Hernando 2015; Martins 2016; Suomi et al. 2019); ii/ the standards and culture within business environment (Yuthavong et al. 1993; Levallois et al. 2021; Vries et al. 2019); iii/ the financial capacity of industry to contribute to academic R\&D (D'Hooghe 2017) iv/ the accessibility of quality research (D'Hooghe 2017; Kim and Jang 2021) v/ the existence of innovation system support measures (van den Bergha and Guild 2008; D'Hooghe 2017; Hassen 2018; Kim and Jang, 2021) and vi/ the government orientation towards creating an innovation-enabling culture (Kim and Jang 2021; Suomi et al. 2019).

\section{Data and Sample}

According to the literature postulated factors of 1 / economic growth and 2/ U-I collaboration, we defined the specific indicators by cross-referencing the existing literature on the topic and the publicly available data. This identified relevant secondary data in the Executive Opinion Survey carried out by the 
World Bank for the purposes of supporting policy makers, business executives and academics in monitoring economic productivity and the abilities of economies to achieve sustained levels of prosperity and growth (The Global Competitiveness Report 2017-2018: 333).

As a result, the proposed model of economic growth defines the growth of Gross Domestic Product per capita (Simionescu et al. 2017) as a function of U-I collaboration (Plewa et al. 2013; Ambroziak et al. 2016; Simionescu et al. 2017) measured by U-I collaboration in R\&D; Financial variables including inflation measured by the Customer Price Index (CPI) (Fischer 1993; Simionescu et al. 2017) trade balance and inward Foreign Direct Investment (FDI) (Alfaro et al. 2004; Gonzalez-Pernia and Pena-Legazkue 2015); with the Entrepreneurship variables - Relative Prevalence (Valliere and Peterson, 2009), Established Business Ownership Rate (в во) (Gonzalez-Pernia and Pena-Legazkue 2015), Nascent Entrepreneurship Rate (van Stel et al. 2005), New Business Ownership Rate (van Stel et al. 2005) and innovation variables represented by Patent numbers (Gonzalez-Pernia and Pena-Legazkue 2015) and R\&D expenditure as a percentage of GDP (R\&D) (Gonzalez-Pernia and Pena-Legazkue 2015; Wong et al. 2005).

The database established incorporated World Bank and Global Innovation Index (GII) data sets.

In the case of the U-I collaboration model, the perceived U-I collaboration was forecast as dependent on policies relating to $i /$ the pool of knowledge, skills and absorptive capacity of stakeholders (Pablo-Hernando 2015; Martins 2016; Suomi et al. 2019) as reflected in the Quality of the education system, Tertiary education enrolment rate and Extent of staff training; ii/ the standards and culture within the business environment (Yuthavong et al. 1993; Levallois et al. 2021; Vries et al. 2019) as represented by Business sophistication; iii/ the financial capacity of industry to contribute to academic R\&D (D'Hooghe 2017) represented by Company spending on R\&D, Ease of access to loans, Effect of taxation on incentives to invest, Availability of financial services; iv/ accessibility to quality research (D'Hooghe 2017; Kim and Jang 2021) reflected by Quality of scientific research institutions and Availability of scientists and engineers; $\mathrm{v} /$ the existence of innovation system support measures (van den Bergha and Guild, 2008; D'Hooghe 2017; Hassen 2018; Kim and Jang, 2021) - the Quality of overall infrastructure; Intellectual property protection; Efficiency of the legal framework in settling disputes; Efficiency of the legal framework in challenging regulations; vi/ the government orientation towards creating an innovation-enabling culture (Kim and Jang 2021; Suomi et al. 2019) represented by Transparency of government policymaking; Burden of government regulation. 
Table 8 in the appendix systematically details the factors included in analysis of the model along with their respective definitions.

Obtained from World Bank and GII data sets, the total sample covers 151 countries. The existing data was grouped into three categories according to the United Nations methodology - developed economies, developing economies excluding Least Developed Countries (LDCs) and LDCs (for the sample summary, see Table 1 in the appendixes). Unfortunately, at the time of this study, we encountered limitations on the data range available and with missing data identified across the data set. Therefore, we accordingly selected two timeframes with data coverage at a minimum level of $90 \%$ for the total sample - 2014-2015 and 2017-2018 (in keeping with the World Bank data collection periods). We analysed both periods separately to optimise the opportunity for providing valuable conclusions despite this lack of consistent time series data.

We made recourse to the SPSS 23 and Excel 2010 software packages to process and estimate the data.

\section{Results}

Verification of the postulated causality between U-I collaboration and economic growth started out with data analysis to validate the regression assumptions. This firstly applied plot analysis to the U-I collaboration data and Gross Domestic Product per capita. As presented in the Figure 2 plots, this returned no indication of any significant positive relationship between the variables. To validate the initial observation, we calculated the correlation coefficients. Due to the lack of any observed linear relation, we applied Spearman's correlation. As set out in Table 2, the correlation coefficients confirmed, as reported by the plot analysis, the lack of any significant positive correlation between
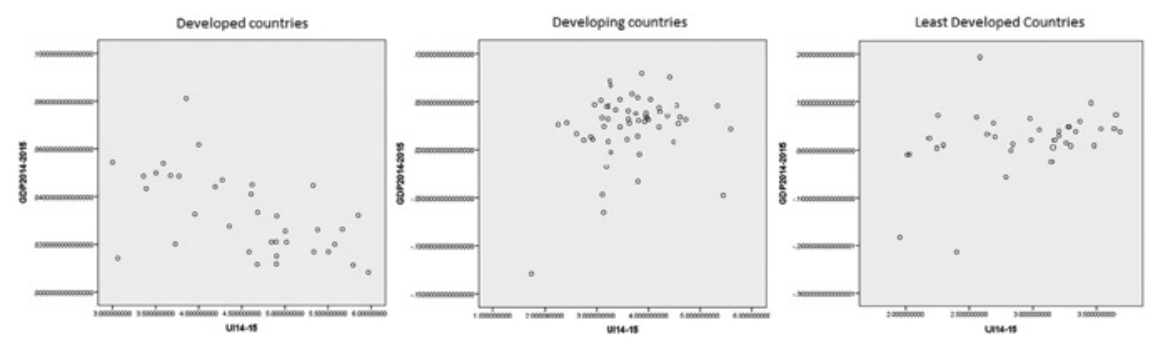

FIGURE 2 Relationship between U-I collaboration and Gross Domestic Product per capita Growth 
TABLE 2 Correlations between U-I collaboration data and gross domestic product per capita growth

\begin{tabular}{llllc}
\hline & Correlation & Developed & Developing & LDCs \\
\hline UI 14-15 to GDP & Spearman Correlation & -0.588 & 0.17 & 0.383 \\
$2014-2015$ & Coefficient & & & \\
& Sig. (2-tailed) & 0.000 & 0.220 & 0.021 \\
& N & 36 & 54 & 36 \\
UI 14-15 to GDP & Spearman Correlation & -0.633 & 0.217 & 0.205 \\
$2016-2017$ & Coefficient & & & \\
& Sig. (2-tailed) & 0.000 & 0.116 & 0.231 \\
& N & 36 & 54 & 36 \\
\hline
\end{tabular}

Note: we assessed significance at the .oo5 level

the variables. However, as economic effects are commonly observed over time, we carried out a second analytical stage to confirm this lack of the postulated relationship accounting for a possible additional lag in the measurements deployed.

Due to short product lifecycles, the current R\&D perspective is short and constantly shortening (Suomi et al. 2019; BCG 2012). However, it strongly differs between industries, types of innovation (i.e. incremental vs. radical) and organisations (i.e. SMEs vs. multinationals). Practitioners estimate that the average time-to-market takes anything from 14 (Maar 2012) through 22 months (BCG 2012; Van Dyke 2017) for the majority of industries while in some heavily regulated industries the timespan may reach three, seven or even twelve years (van Norman 2016). Considering the survey-based character of U-I collaboration measurement and the majority of industries displaying time-to-market timeframes of below two years, we accounted for a possible lag of about two years on the grounds of the average innovation process duration accounting for a possible delay between recognition of U-I collaboration among respondents and the economic effects. Therefore, we undertook a second plot analysis to analyse the relation between U-I collaboration in 2014-2015 and the 2016-2017 growth of gross domestic product per capita. Figure 3 and Table 2 provide the results that also does not confirm any positive correlation between these variables in terms of their lagged effects.

The initial results demonstrate how in no group of countries did the level of U-I collaboration achieve a significant positive impact on economic growth. 

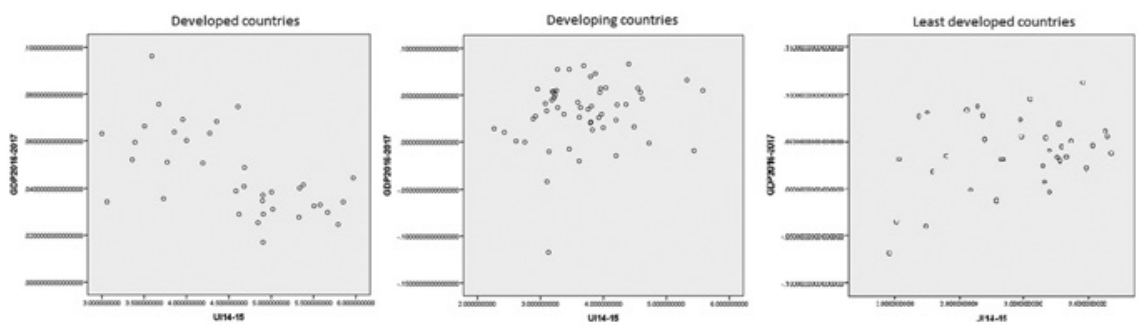

FIGURE 3 Relationship between 2014 U-I collaboration and 2016-2017 Gross Domestic

Product per capita Growth

The impact of U-I collaboration was already insignificant at the stage of correlation analysis proving further regressions counterproductive. Therefore, the study reports no evidence supporting the $\mathrm{H} 2$ hypothesis. Despite the postulated importance of U-I collaboration for economic development, the study does not provide any evidence of a significant positive impact of U-I collaboration on economic growth. The effect may potentially derive from either overly limited effective outputs from U-I collaboration, which did not globally reach the critical mass required to obtain the postulated benefits of U-I collaboration; the lack of quality or effectiveness of ongoing U-I collaborations or simply the underutilization of knowledge and the results of collaboration.

On the other hand, comparing the list of top innovators with the list of countries with the best U-I collaboration performance levels conveys how the highest levels of U-I collaboration do not stem only from countries with the highest development levels and innovation leaders. Top innovators among developed countries such as Switzerland (5.77), Japan (4.74) or the USA (5.71) are among the top achievers in that category. However, among others, developing and least developed countries such as Kenya (4.3) and Guinea (5.03) report higher levels of U-I collaboration than many developed countries (see Figure 4).

In the light of previous studies highlighting the positive impact of U-I collaboration on economic growth (Salem and Amjed 2008; van den Bergha and Guild 2008; Sandberg et al. 2015), our results in terms of $\mathrm{H}_{2}$ underline the need for improving the extent and/or quality of U-I collaboration and/or capitalisation on the results of collaboration to effectively realise that postulated in the positive literature on the impact of U-I collaboration. Therefore, maintaining the study design and the need for policy-related research encouraging intersphere collaboration (Mark et al. 2014; Kim and Jang, 2021), we now provide analysis of the relation between policy-related factors and U-I collaboration in countries at different development levels. Here, we focus on specific factors of the innovation system resulting from public measures and the overall R\&D 


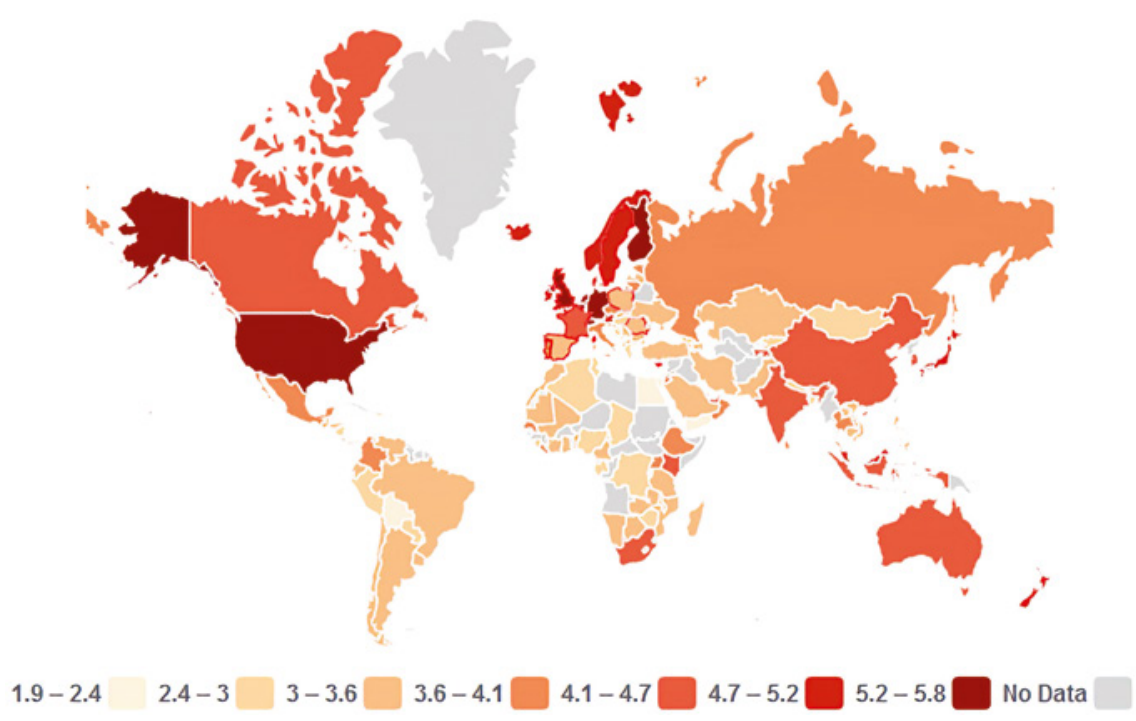

FIGURE 4 University-industry collaboration in Research \& Development, Index 2017-2018 SOURCE: THE WORLD BANK - HTTPS://TCDATA360.WORLDBANK.ORG

environment with the potential to enhance U-I collaboration with stronger impacts. As presented in the methodology section, our analysis covers a broad number of variables as expected predictor variables:

$\mathrm{E}($ UI_collaboration $)=$

$=\mathrm{f}$ (Transparency of policymaking, Availability of scientists and engineers, Availability of financial services, Burden of government regulation, Business sophistication, Company spending on research \& development, Ease of access to loans, Effect of taxation on incentives to invest, Efficiency of the legal framework in challenging regulations, Efficiency of the legal framework in settling disputes, Extent of staff training, Intellectual property protection, Quality of overall infrastructure, Quality of scientific research institutions, Quality of the education system, Tertiary education enrolment).

Due to the large number of potential factors, in order to achieve our study objectives, we deployed a stepwise procedure to obtain the optimal match of the model through the identification of critical success factors for U-I collaboration within the defined groups of countries. 
Resulting from the stepwise procedure, the multiple regression model within developed countries (covering 37 countries in the data set (see Table 1 in the Appendixes) identified three significant factors for U-I collaboration: the quality of research institutions (2014-2015: $\left.\mathrm{B}_{\mathrm{i}}=.727 ; 2017-2018: \mathrm{B}_{\mathrm{i}}=.45^{2}\right)$, private $R \& D$ investments $\left(2014-2015: \mathrm{B}_{\mathrm{i}}=.137 ; 2017-2018\right.$ : $\left.\mathrm{B}_{\mathrm{i}}=.477\right)$ and bureaucratic burden (2014-2015: $\left.\mathrm{B}_{\mathrm{i}}=.259 ; 2017-2018: \mathrm{B}_{\mathrm{i}}=.205\right)$ as predictors of U-I collaboration (see Table 3 , the full output is attached in the Appendixes section).

While the importance of the three factors is confirmed across both the periods analysed, the results from the 2014-2015 period report a stronger impact from research institution quality over private R\&D investments. Meanwhile, the 2017-2018 results attribute a primary role to private R\&D investments for U-I collaboration within the developed countries group.

For the developing countries group, with the 2014-2015 data covering 55 countries (see table 1 in the Appendixes), the stepwise procedure resulted in a complex model including eight independent variables as factors influencing U-I collaboration (see Table 4). The estimation results demonstrate the high significant and positive impacts of Quality of research institutions $\left(B_{1}=.498\right)$, Private $R \& D$ investments $\left(B_{2}=.486\right)$ and Staff training $\left(B_{3}=.251\right)$ on U-I collaboration. The transparency of policy making $\left(\mathrm{B}_{4}=.48 \mathrm{o}\right)$ and the Ease of access to loans $\left(B_{5}=.140\right)$ also positively and significantly impact on U-I collaboration

TABLE 3 Models of U-I collaboration in developed countries

Model Period Included variables

1

\begin{tabular}{|c|c|c|c|c|c|}
\hline $\begin{array}{l}2014- \\
2015\end{array}$ & $\begin{array}{l}\text { Adj. R Square } \\
\text { o.942 }\end{array}$ & Constant & $\begin{array}{l}\text { Quality of } \\
\text { research } \\
\text { institutions }\end{array}$ & $\begin{array}{l}\text { Bureaucratic } \\
\text { burden }\end{array}$ & $\begin{array}{l}\text { Private R\&D } \\
\text { investments }\end{array}$ \\
\hline & Coefficients (B) & -0.513 & 0.727 & 0.259 & 0.137 \\
\hline & $\begin{array}{l}\text { Significance } \\
{[\mathrm{t}(\text { sig })]}\end{array}$ & $\begin{array}{l}-2.048 \\
(.049)\end{array}$ & $9.969(.000)$ & $4.711(.000)$ & $2.220(.034)$ \\
\hline $\begin{array}{l}2017- \\
2018\end{array}$ & $\begin{array}{l}\text { Adj. R Square } \\
0.948\end{array}$ & Constant & $\begin{array}{l}\text { Private } R \& D \\
\text { investments }\end{array}$ & $\begin{array}{l}\text { Quality of } \\
\text { research } \\
\text { institutions }\end{array}$ & $\begin{array}{l}\text { Bureaucratic } \\
\text { burden }\end{array}$ \\
\hline & Coefficients (B) & -0.787 & 0.477 & $0.45^{2}$ & 0.205 \\
\hline & $\begin{array}{l}\text { Significance } \\
{[\mathrm{t}(\text { sig })]}\end{array}$ & $\begin{array}{l}-2.746 \\
(.011)\end{array}$ & $4.932(.000)$ & $4.077(.000)$ & $2.668(.013)$ \\
\hline
\end{tabular}

Note. Final models of U-I collaboration verified according to the .o5 level of confidence. 
TABLE 4 The initial model of U-I collaboration in developing countries (without LDCs) 2014-2015

\begin{tabular}{|c|c|c|c|c|c|c|}
\hline & & \multicolumn{2}{|c|}{$\begin{array}{l}\text { Unstandardized } \\
\text { Coefficients }\end{array}$} & \multirow{2}{*}{$\begin{array}{l}\text { Standardized } \\
\text { Coefficients } \\
\text { Beta }\end{array}$} & \multirow[b]{2}{*}{$\mathbf{t}$} & \multirow[b]{2}{*}{ Sig. } \\
\hline \multicolumn{2}{|c|}{ Model } & B & Std. Error & & & \\
\hline \multirow[t]{9}{*}{8} & (Constant) & $-.6 \circ 2$ & .225 & & -2.674 & .011 \\
\hline & ResInstQ14-15 & .498 & .083 & .520 & 5.986 & .000 \\
\hline & PRVR\&D14-15 & .486 & .102 & .447 & $4 \cdot 75^{1}$ & .000 \\
\hline & StafTR $14-15$ & .251 & .086 & .186 & 2.906 & .006 \\
\hline & EducQ14-15 & -.108 & .055 & -.129 & -1.957 & .058 \\
\hline & LoanAc14-15 & .140 & .064 & .155 & 2.199 & .034 \\
\hline & SetDisp14-15 & -.330 & .073 & -.378 & -4.488 & .000 \\
\hline & Tranp14-15 & .480 & .111 & .464 & 4.334 & .000 \\
\hline & BurecrBurd14-15 & -.256 & .105 & -.242 & -2.431 & .020 \\
\hline
\end{tabular}

within this model. Meanwhile, Bureaucratic burden $\left(\mathrm{B}_{6}=-.256\right)$ and Education quality $\left(\mathrm{B}_{7}=-.108\right)$ provide negative impacts for U-I collaboration.

While the literature, as well as a general understanding, commonly support the negative impact of bureaucratic burden on U-I collaboration (Plewa et al., 2013), the negative relationship between the quality of education and U-I collaboration does not often gain recognition, especially the opposite impact of the quality of research institutions and education quality may raise doubts regarding the model. However, the negative relationship, especially in this specific country group, may suggest that the increased quality of education in the private sector generates higher innovation capacities and the dependence on universities in providing innovation correspondingly decreases.

To ensure the study ensures the quality of its contribution, we carefully re-examined the theory and procedures. The significance of each independent variable reports that Quality of education does not meet the criterion of the 0.05 confidence level (see Table 4). Considering the regression objective of identifying the crucial factors of success related with support for U-I collaboration, as the literature provided no strong theoretical reasons to retain the variable in the model, we excluded this variable from the list of variables before performing a second regression with stepwise procedure on the new more limited variable list (Welfe 2008). The adjusted procedure resulted in a 
Model and

Period
Included variables

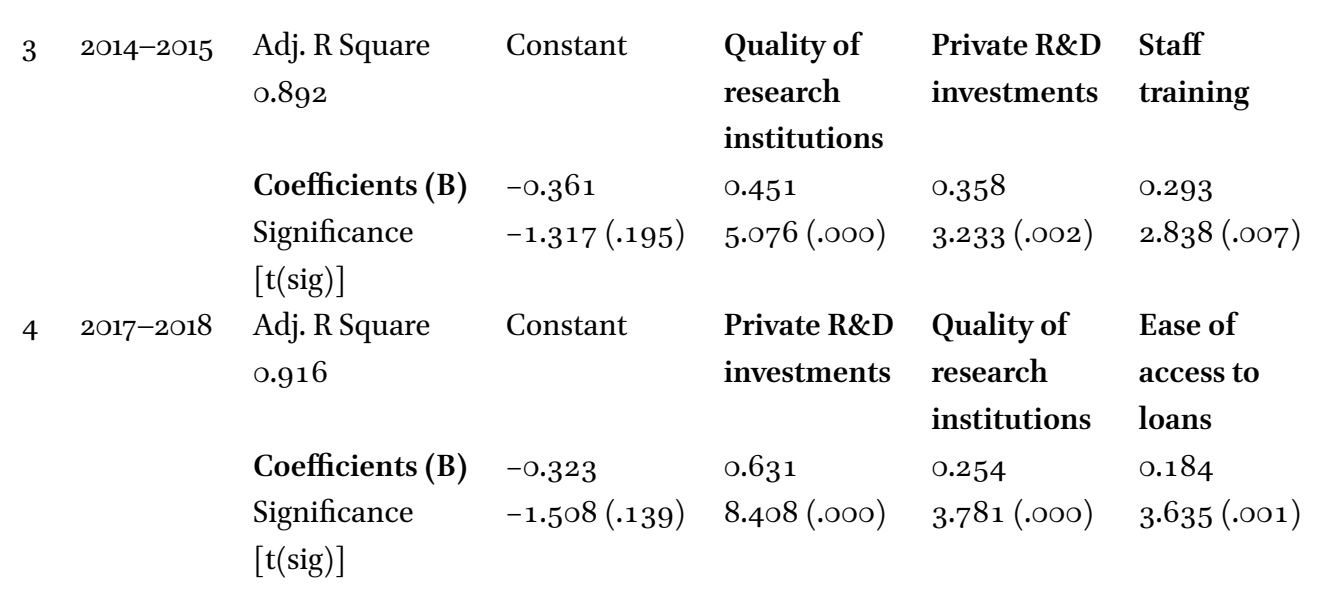

Note. The final U-I collaboration models obtained according to the .o5 level of confidence.

model with three significant independent variables as predictors of U-I collaboration. Model 3 presented in Table 5 reports a strong positive impact of Quality of research institutions $\left(B_{1}=.451\right)$, Private R\&D investments $\left(B_{2}=.358\right)$ and Staff training $\left(\mathrm{B}_{3}=.293\right)$ on U-I collaboration in developing countries, excluding the LDCs.

The same procedure for the 53 developing countries available for the 20172018 period resulted in model 4 presented in Table 2. The Quality of research institutions $\left(\mathrm{B}_{1}=.254\right)$ and Private $\mathrm{R} \& \mathrm{D}$ investments $\left(\mathrm{B}_{2}=.631\right)$ were the factors with the strongest impacts positively influencing the U-I collaboration over that period followed by Ease of access to loans $\left(B_{3}=.184\right)$.

Meanwhile, according to the estimation results presented in Table 3 , in the period 2014-2015, the U-I collaboration in LDCs significantly interlinked only with the quality of research institutions $\left(\mathrm{B}_{1}=.811\right)$. Furthermore, as presented in Table 6, resulting from the estimation for 2017-2018 period, model 6 incorporates three independent variables - private $R \& D$ investments $B_{1}=.938$ and staff training $B_{2}=.583$ with positive impacts and the negative impact of bureaucratic burden $\mathrm{B}_{3}=-.256$.

To reach conclusions on the established hypotheses, all six models verified according to the 0.05 level of confidence were subject to comparative analysis. Comparison of the regression results (see Table 7 ) and their analysis identify 
TABLE 6 Models of U-I collaboration in LDCS

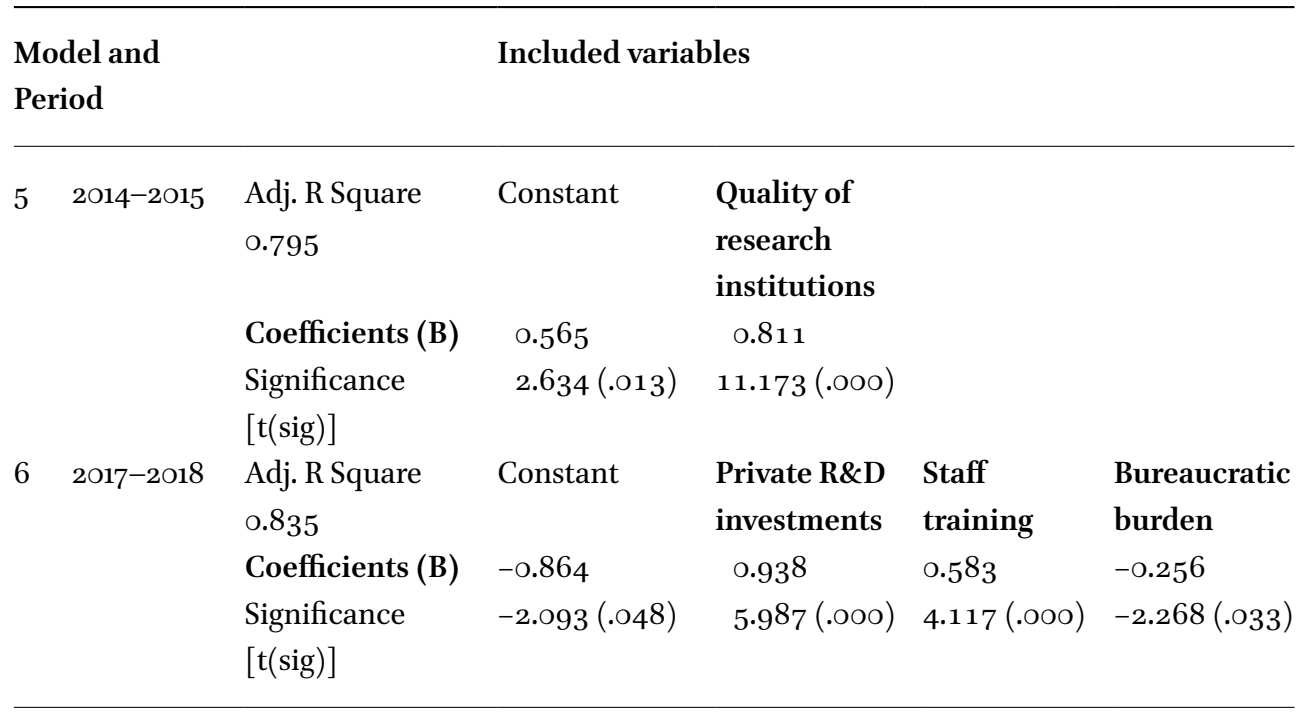

Note. The final U-I collaboration models obtained according to the .o5 level of confidence.

TABLE 7 Models of U-I collaboration - summary

Model Period Adj. R Square Included variables

2

\begin{tabular}{|c|c|c|c|c|c|}
\hline \multirow[t]{3}{*}{$\begin{array}{l}2014^{-} \\
2015\end{array}$} & $\begin{array}{l}\text { Adj. R Square } \\
\text { o.942 }\end{array}$ & Constant & $\begin{array}{l}\text { Quality of } \\
\text { research } \\
\text { institutions }\end{array}$ & $\begin{array}{l}\text { Bureaucratic } \\
\text { burden }\end{array}$ & $\begin{array}{l}\text { Private R\&D } \\
\text { investments }\end{array}$ \\
\hline & Coefficients (B) & -0.513 & 0.727 & 0.259 & 0.137 \\
\hline & $\begin{array}{l}\text { Significance } \\
{[\mathrm{t}(\operatorname{sig})]}\end{array}$ & $-2.048(.049)$ & $9.969(.000)$ & $4.711(.000)$ & $2.220(.034)$ \\
\hline \multirow[t]{3}{*}{$\begin{array}{l}2017^{-} \\
2018\end{array}$} & $\begin{array}{l}\text { Adj. R Square } \\
\text { o.948 }\end{array}$ & Constant & $\begin{array}{l}\text { Private } R \& D \\
\text { investments }\end{array}$ & $\begin{array}{l}\text { Quality of } \\
\text { research } \\
\text { institutions }\end{array}$ & $\begin{array}{l}\text { Bureaucratic } \\
\text { burden }\end{array}$ \\
\hline & Coefficients (B) & -0.787 & 0.477 & $0.45^{2}$ & 0.205 \\
\hline & $\begin{array}{l}\text { Significance } \\
{[\mathrm{t}(\text { sig })]}\end{array}$ & $-2.746(.011)$ & 4.932 (.ooo) & 4.077 (.00o) & $2.668(.013)$ \\
\hline \multirow[t]{2}{*}{$\begin{array}{l}2014- \\
2015\end{array}$} & $\begin{array}{l}\text { Adj. R Square } \\
\text { o.892 }\end{array}$ & Constant & $\begin{array}{l}\text { Quality of } \\
\text { research } \\
\text { institutions }\end{array}$ & $\begin{array}{l}\text { Private R\&D } \\
\text { investments }\end{array}$ & Staff training \\
\hline & Coefficients (B) & -0.361 & $0.45^{1}$ & $0.35^{8}$ & 0.293 \\
\hline
\end{tabular}




\begin{tabular}{|c|c|c|c|c|c|c|}
\hline & & $\begin{array}{l}\text { Significance } \\
{[\mathrm{t}(\text { sig })]}\end{array}$ & $-1.317(.195)$ & $5.076(.000)$ & $3.233(.002)$ & $2.838(.007)$ \\
\hline \multirow[t]{3}{*}{4} & $\begin{array}{l}2017^{-} \\
2018\end{array}$ & $\begin{array}{l}\text { Adj. R Square } \\
0.916\end{array}$ & Constant & $\begin{array}{l}\text { Private R\&D } \\
\text { investments }\end{array}$ & $\begin{array}{l}\text { Quality of } \\
\text { research } \\
\text { institutions }\end{array}$ & $\begin{array}{l}\text { Ease of access } \\
\text { to loans }\end{array}$ \\
\hline & & Coefficients (B) & -0.323 & 0.631 & 0.254 & 0.184 \\
\hline & & $\begin{array}{l}\text { Significance } \\
{[\mathrm{t}(\text { sig })]}\end{array}$ & $-1.508(.139)$ & 8.408 (.ooo) & $3.781(.000)$ & $3.635(.001)$ \\
\hline \multirow[t]{2}{*}{5} & $\begin{array}{l}2014^{-} \\
2015\end{array}$ & $\begin{array}{l}\text { Adj. R Square } \\
\text { o.795 }\end{array}$ & Constant & $\begin{array}{l}\text { Quality of } \\
\text { research } \\
\text { institutions }\end{array}$ & & \\
\hline & & $\begin{array}{l}\text { Coefficients }(\mathrm{B}) \\
\text { Significance } \\
{[\mathrm{t}(\text { sig })]}\end{array}$ & $\begin{array}{l}0.565 \\
2.634(.013)\end{array}$ & $\begin{array}{c}0.811 \\
11.173(.000)\end{array}$ & & \\
\hline \multirow[t]{3}{*}{6} & $\begin{array}{l}2017^{-} \\
2018\end{array}$ & $\begin{array}{l}\text { Adj. R Square } \\
\text { o.835 }\end{array}$ & Constant & $\begin{array}{l}\text { Private R\&D } \\
\text { investments }\end{array}$ & Staff training & $\begin{array}{l}\text { Bureaucratic } \\
\text { burden }\end{array}$ \\
\hline & & Coefficients (B) & -0.864 & 0.938 & 0.583 & -0.256 \\
\hline & & $\begin{array}{l}\text { Significance } \\
{[\mathrm{t}(\text { sig })]}\end{array}$ & $-2.093(.048)$ & $5.987(. \circ \circ \circ)$ & $4.117(.000)$ & $-2.268(.033)$ \\
\hline
\end{tabular}

Note. The final models of U-I collaboration obtained according to the .o5 level of confidence.

how the different development levels relate to different levels of policy measure impacts with different policies holding relevance for national U-I collaboration at different levels of development. These findings therefore support $\mathrm{H}_{1}$ : the positive influences of policy interventions on U-I collaboration differ between countries at different development levels.

As there was no confirmation of any significant positive impact of U-I collaboration on economic growth within the current data set across any of the defined development levels, there was also no evidence that U-I collaboration will stimulate stronger economic growth in less developed countries. Hence, at this stage, we are unable to report evidence to support our $\mathrm{H}_{2}$ that U-I collaboration will generate a stronger impact on economic growth in less developed countries. 


\section{Discussion of Results}

According to the theoretical review and the objectives established, our research model postulated 1 / significant differences in the positive influence of U-I collaboration on economic growth in countries at different levels of development $(\mathrm{H} 2)$, and $2 /$ that the positive influence of policy interventions on U-I collaboration differs between countries at different levels of development $(\mathrm{H1})$.

\section{U-I Collaboration and Economic Growth}

Against expectations, our data analysis did not return evidence that U-I collaboration at the current stage provides significant positive impacts on economic development at the macro level. This lack of evidence of any positive impact was independent of the development level. There was also no statistical support for $\mathrm{H}_{2}$ - that U-I collaboration stimulates stronger economic growth in less developed countries. While literature commonly posits a relevant impact of U-I collaboration on economic growth (Macleod et al.1997; Salem and Amjed 2008; van den Bergha and Guild 2008; Sandberg et al. 2015), such an effect was not confirmed in our study. Unfortunately, the lack of previous cross-sectional studies of this relationship at the macro level does not allow for any direct comparison of results. However, previous regional level studies have demonstrated that knowledge spill-overs from universities do not necessarily need to provide their postulated economic benefits. An empirical study of Italian regions by Cowan and Zinoryeva (2013) identifies how regions with lower per capita income, relatively low R\&D investment levels and less educated labour forces benefit from knowledge spill-overs from universities. Meanwhile, on average, there were no positive university spill-over effects observed for the high-income regions. On the contrary, a study of the developed regions of West Germany by Mueller (2006) shows a positive impact of U-I collaboration on economic development. Regrettably, no effect assessment focused study has approached non-developed countries.

The limited preceding studies suggest that even in the case of developed regions, there are significant disparities in the effects of U-I linkages on economic development. Hence, the disparities in effects within each country group might potentially lead to the average effect within the country group being non-significant as in our results. The literature also underlines how U-I collaboration knowledge often gets underutilised which prevents its translation into economic effects (Mueller 2006). Such underutilization may result from either risk aversion or existing U-I barriers. However, production capacity 
and stage of development related factors, such as the technology available and access to qualified human resources, also produce impacts.

Therefore, we do not conclude from these results that U-I collaboration provides no benefits for economic development. Within the context presented, our study instead suggests that countries at all levels of development struggle to attain a significant level and quality of U-I collaboration that effectively reflects on their economic development. Our results empirically reflect the common belief that the progress in the level and quality of U-I collaboration in the field of innovation has hitherto remained insignificant. That lack of effective translation of U-I collaboration into direct economic benefits represents a universal issue (Rad et al. 2015; Peng et al. 2017; Suomi et al. 2019) leading to global losses due to the failure to effectively leverage the potential benefits from U-I collaboration. This finding suggests that more efficient approaches to encouraging, improving and exploiting U-I collaborations that resolve realistic needs (Hassen 2018; Kim and Jang, 2021) might bring significant competitive advantages to the economies successfully implementing them. Our study empirically supports calls from both practitioners and academics for improved analysis of strategies and instruments in this field. This furthermore requires more thorough knowledge-based policy-making processes to obtain the U-I benefits postulated for the economy and society (Mowery and Sampat 2004; Mark et al. 2014; OECD, 2019). Designing strategies capable of overcoming that indicated by our results; market and system failures [will require] excellent knowledge of $[\ldots]$ institutional context $[\ldots]$ that will allow policymakers to design place-based policies adapted to their regional context (EU, 2020).

\section{The Enabling Character of Policies and Support Mechanisms for $U$-I Communication}

While in the light of our results, undertaking efforts to support U-I collaboration might appear daunting to policymakers, increased efforts are necessary due to the shift in global competition toward knowledge and innovation. However, its great relevance also derives from the empirically proven positive impact of U-I collaboration on such aspects as private R\&D, competitiveness and company growth (Berman 1990; Mark et al. 2014). While the critical-mass for obtaining significant direct effects from U-I collaboration on economic growth at the national level may be lacking, U-I collaboration contributes to economic development indirectly through critical impacts on company innovativeness and competitiveness.

Furthermore, our results empirically demonstrate that, when designing support strategies for U-I collaboration and seeking the right policy-mix, decision-makers should take into account the specific national development level. The data analysis findings allowed us positively validate $\mathrm{H} 1$ postulating 
that the enabling character of U-I collaboration policies and mechanisms differs between countries at different development levels. Our analyses of the impacts of policy-related indicators on U-I collaboration empirically identify the different impacts of U-I collaboration policy-related factors in countries at different levels of development (see Table 7). Our results suggest the quality of research institutions and private R\&D investment in developed countries play critical roles. To obtain significant economic growth and innovative levels of U-I collaboration, universities need to generate high-quality research outputs and ensure their positive perception by external agents. Such results align with Mark et al. (2014) who underline how research focused universities are more likely to generate economic effects. More, in keeping with Cowan and Zinoryeva (2013), this stresses the need to highlight research and ensure its quality as well as its recognition among stakeholders. Within the policy scope, the results suggest that increasing the capacity to undertake high quality applied research within the academic sector is of high relevance. Additionally, this also conveys how better and more transparent (to the public) systems for evaluating the quality of research institutions might foster the interest of industrial partners in academic research and co-innovation. However, these results do not align with the thesis postulated by Vries et al. (2019) that in establishing U-I knowledge transfers applicability, rather than quality, is of the essence.

From another perspective, our results describe how industry needs to provide financial compensation for those universities devoting their attentions to the commercialisation of their research. This directly aligns with the literature suggesting that access to high-level private $R \& D$ funding leads to the best performance within the scope of U-I collaboration for innovation. As such, the best results arisen from the heavily privately funded fields such as biotechnology and the information and communication technologies. However, these are also the fields in which academic engagement is considered of the highest market value (D'Hooghe 2017; Hayden et al. 2018). This suggests that in developed countries with high levels of private R\&D investments, such measures as cutting public financing for academic research might represent an effective stimulus for academic engagement in U-I collaboration and may increase the focus of academics on quality research standards. D'Hooghe (2017) reports how, based on the example of reproductive medicine, successful U-I collaborative research in 'non-headline' research fields may derive from lacking access to public finance increasing the requirements for more strongly market oriented research. Additionally, policies favouring the financial engagement of private $R \& D$ funds with academic research and especially co-innovation may help in fostering industrial engagement.

Moreover, our study results suggest the positive impact of the bureaucratic burden in developed countries. While the bureaucratic burdens do not 
commonly get associated with positive impacts, the study suggests that welldesigned administrative mechanisms with a well-designed mix of effective innovation policies within NIS may constitute an enabling character for U-I collaboration in the innovation area (Gann et al. 1998; Freitas and Tunzelman 2008; Coccia 2009). An increase in support measures, including financial support, commonly interrelates with increases in bureaucratic burdens. Studies report that the bureaucratization related to administrative burden needs to be kept at the level necessary for the governance of structures. Furthermore, negative effects result when administrative bureaucratization involves increases in the numbers of administrative staff in excess of the research and operational staff (Coccia 2009). This underlines how ensuring an optimal level of bureaucratization able to support rather than jeopardize the U-I collaboration represents a challenge to governance. This especially emphasises the need for the attentive and intelligent design of regulatory instruments to promote U-I collaboration. Instruments such as the IPR regime or academic spin-off regulations emerge as highly relevant in developed countries but need designing in ways able to contribute rather than obstruct U-I knowledge transfers and co-innovation (OECD, 2019). However, in sum, the results clearly support the potential for the enabling character of U-I collaboration policy-measures.

In developing countries, similar to their developed counterparts, our results convey the importance of research institution quality and private R\&D investments across both analysed periods. Furthermore, the regression results identify the significance of staff training (2014-2015) and the ease of access to loans (2017-2018). Once again, in the second period (2017-2018), we observe an increased impact of private R\&D investments on U-I collaboration. The shift between the quality of research organisations (2014-2015) and private R\&D investments (2017-2018), as the most impactful factor for U-I collaboration, may suggest that the crucial collaboration initiation role shifted from the university to the business sphere between those two periods. This may result from an increasing private sector awareness of the benefits of U-I collaboration and their increasing capacity to benefit from them (Vanhaverbeke 2017). However, this may also relate to the specifics of the economic cycle with the lack of scope for financing in 2014 needing to be offset by existing internal human resource capacities. This rationale reflects in the positive impact of staff training in 2014-2015 interrelated with that postulated in the absorptive capacity literature (Martins 2016; Hassen 2018). Its significance was replaced in the 2017-2018 period by ease of access to loans as a factor supporting private $\mathrm{R} \& \mathrm{D}$ investments and the willingness to take risks.

In addition, the quality of research institutions predicted the U-I collaboration level within LDCs in the first period. In fact, in the first period (2014-2015), 
this was the only predictor of U-I collaboration in LDCs. The strong positive impact may underpin the crucial role of research institutions as the engine for U-I collaboration and knowledge transfers to the private sector in LDCs as postulated in the literature. In this specific development group, this may provide a critical mechanism due to the lack of proper innovation assets in place (Macleod et al., 1997; Cowan and Zinoryeva 2013). In the second period analysed (2017-2018), U-I collaboration in LDCs positively relates to private R\&D investments and staff training and receives a negative impact from the bureaucratic burden. This underlines the need to place a specific focus on stimulating private-sector-oriented policies for increasing private funding for research and innovation and developing the absorptive capacity in LDCs. However, special attention also need paying to minimising the bureaucratic barriers in LDCs where U-I collaboration is significantly hindered by bureaucratic barriers. Such obstacles commonly discourage engagement with public sector research institutions (Kim and Jang 2021).

Our study portrays the different impacts of policy-related factors on U-I collaboration in countries at different development levels. As posited by some authors, this confirms the need for strategies adapted to the needs of different regions rather than any transfer of best practices from the most developed countries (Salem and Amjed 2008; Teller and Validova 2015; Ankrah and Omar 2015). The results also reflect the points made by the OECD report on the importance of U-I collaboration support policy options taking into consideration both the complexity of the strategies required and the need to analyse policies not individually but as a policy-mix in order to seek out synergetic rather than concurrent effects (OECD 2019). However, our results suggest this should also consider specific economic and institutional factors and strategic objectives (OECD 2019; Teller and Validova 2015; Mowery and Sampat 2004; Galàn-Muros and Plewa 2016). They also suggest that the specific policy mix should be flexible enough to react to changing environmental conditions and subject to periodic review to provide effective assistance for U-I collaboration. Whilst in developed countries, the needs for specific policy interventions seem more stable over time, especially countries at the lowest level of development may often require revisions of policy-mixes and correspondingly making changes to the key areas of intervention.

Meanwhile, some policy measures emerged with transversal importance. U-I collaboration was especially positively influenced by the quality of research institutions and private R\&D investments. This underlines the need to implement efficient strategies to boost the quality of research institutions and incentives for private $R \& D$ investments to generate significant levels of U-I collaboration. Such a result is especially important as modern policy 
recommendations often overlook or marginalise this aspect. Stimulating the quality of research institutions was not directly addressed in the recent Interreg Policy Brief (EU, 2O20). In the OECD report on policy options for universityindustry collaboration, of the twenty-one instruments for nurturing U-I collaboration only one directly relates to the issue - performance-based funding systems for university linkages with industry. Considering our results, such systems should strongly underline the role of U-I collaboration and monitor the quality of such interactions and encourage quality in applied academic research. However, further instruments for improving quality of research institutions also require consideration.

Interestingly, in every country group, private $R \& D$ investments returned a major impact on U-I collaboration in 2017-2018, while its significance was lower or non-existing in the 2014-2015 period. In the initial study period (2014-2015), the quality of research institutions was the major (or in the case of LDCs the only) significant factor influencing the level of U-I collaboration. On the one hand, this suggests that, in the initial stage, the quality of research institution constitutes the key factor determining whether U-I collaboration for innovation occurs. This may either associate with university competencies or reputation as the results from the developed and developing countries (with the exclusion of LDCs) would suggest. However, this may also arise from the university's key role as the engines driving U-I collaboration. This aspect derives especially from the lack of significance of private sector factors in LDCs in the initial period.

The increased role of the industry factor (private R\&D investments) in the second period (2017-2018) may suggest that, over time, industry has more closely engaged in fostering U-I collaboration within the scope of innovation. This may eventually result from a better understanding of the benefits to industry from knowledge transfers or dropping barriers to U-I collaboration as this matures on the national scale. On the other hand, as previously mentioned, the result may also stem from the impact of the economic cycle and changing restrictions on access to financing. As the reasons postulated remain unclear, the cause of this shift deserves further examination. Should the shift interrelate with the economic cycle, the results could suggest that knowledge resources and private $R \& D$ investments can have substitutive character. This may therefore imply that when access to financing for the private sector is more difficult, providing additional knowledge resources and increasing the absorptive capacities of companies constitute relevant policy measures for offsetting the negative impacts of economic recessions. Should such effects be further substantiated by empirical research, such findings may reflect in important implications for decision-makers. In such instance, effective U-I 
collaboration would not only significantly contribute to economic development but could also become a relevant instrument for countering economic downturns through specific policies especially increasing/facilitating access to innovation assets and co-innovation opportunities during the recession.

Limitations on private sector capacities to finance $R \& D$ investments emerge as a barrier to U-I collaboration across all development levels. The transversal and significant role of access to loans for developing countries (excluding LDCs) underlines the importance of supporting private R\&D investments. In addition to the OECD proposed instruments of tax incentives and direct financial support for spin-offs and the recruitment of academic researchers by industry (OECD 2019), the development of risk capital markets and financial institutions supporting industry and U-I innovation constitute an important policy axis within the scope of supporting U-I collaboration for innovation.

Furthermore, the opposite impact of the bureaucratic burden in both developed and least developed countries demonstrate how it is the type of measures implemented and the prevailing standard of governance that determine their impacts on the U-I collaboration level. The aforementioned OECD report recognises such feasible impacts and advocates for policymakers endowing research institutions with greater autonomy over how they collaborate with industry (OECD 2O19).

Based on these results, an optimal strategy for supporting U-I collaboration in the area of innovation should be responsive to specifics of the economy, periodically revisited according to the changing needs of the market and U-I collaboration stakeholders and be designed as an integrated policy-mix. Our results empirically support the need for strategies adapted to the needs of different regions rather than transferring best practices from the most developed countries. Furthermore, they also convey how support measures need to consider the current state of the economic cycle.

\section{Conclusions}

Nowadays, countries across the globe strive to embrace innovation as the means for economic development, competitiveness and improving the quality of citizens' lives. Within this scope, both industry and academia are crucial knowledge partners for governments to maximise the benefits produced from national resources. Successful government support measures for U-I collaboration may stimulate U-I co-innovation and generate significant competitive advantages. However, this requires the competent implementation of support strategies that meet the realistic needs of both university and industry and 
accounting for the specific economic conditions prevailing. Meanwhile, there is scarce evidence detailing the actual effectiveness of support measures and policies in different economic conditions. To contribute to this discussion, this study analyzed the relationship between U-I collaboration and economic development and how specific government measures may impact on U-I collaboration in countries at different levels of development.

The positive economic effects of U-I collaboration demonstrated in the literature involve enhancing the innovativeness and competitiveness of companies. However, our study did not return evidence of a statistically significant positive direct impact of U-I collaboration on economic growth at the macro level. Our study suggests that the potential of U-I collaboration remains underutilized across all levels of development. This implies that, despite current common efforts to capitalise on U-I synergies, more effective strategies are needed. In accordance with the previous literature (Salem and Amjed 2008; Rad et al. 2014), our research confirms the need for solutions tailored to the different economic characteristics of countries. In addition, this underlines how in countries at lower development levels, policies should be periodically revisited to react to ongoing changes in the economic and institutional environments.

Moreover, analysis of the differences between the two periods analysed conveys how in the first period, when access to financial resources was more obstructed, the relevance of knowledge and innovation assets for U-I collaboration was higher than that of financial resources. The relationship inverted when access to financing became easier. Such a shift may imply that U-I collaboration for innovation attains particular importance in times of economic crisis and may potentially support business performance in times when there are greater obstacles to accessing external financing. This also identifies how the potential of U-I collaboration and the interrelationship with the prevailing economic contexts need better understanding. Effective support for U-I collaboration will require intelligent policy making taking into account the complexity of the respective institutional and socioeconomic environments. The research especially shows that a strong knowledge-based approach to policies related with U-I collaboration and proper governance is necessary as their design may result in both positive and negative impacts on U-I collaboration. While the impact factor differs between groups and periods, the research institution quality and private $R \& D$ investments emerged as critical and transversal factors to U-I collaboration. Therefore, they respectively both deserve strong encouragement and promotion. Furthermore, in the groups of less developed countries, staff training displays a relevant role, suggesting the need for public support for adult and vocational education in peripheral and emerging regions to enable U-I collaboration for innovation. However, applied 
measures need analysing as a policy-mix within a specific context rather than as a sum of independent policies as interactions between specific instruments play a relevant role.

The study, seeking to fill the gap in quantitative research on U-I collaboration faced several limitations. In the first place, these related to the current availability of data. Studies of U-I relations do not commonly extend beyond those associated with U-I collaboration and knowledge transfers. Meanwhile, innovation is not only impacted by such institutionalised U-I interactions. While there is recognition of formal U-I collaborations as generating the greatest impact on innovation, the literature also proposes informal interactions and cross-fertilising ideas across different agents as also playing a meaningful role. However, as at the time of study, to the best of our knowledge there is no existing data encapsulating non-institutionalised communications within the scope of U-I collaboration. Therefore, in keeping with the existing data, our analytical focus here falls on U-I collaboration. Specific indicators not accounting for different forms of collaboration and reporting the perceived level of UI collaboration might impact on the results obtained. Any further extension of both data sets and research into U-I relations at different development levels should also consider non-formalised U-I interactions and thereby test our hypothesis based on alternative measurements of UI collaboration. In addition, the difficulty in obtaining well-established global data for U-I collaboration has limited our scope for thoroughly exploring the possible relationships. The data provided by the World Bank data do not provide sufficient coverage of observations over a timeframe susceptible to analyzing whether the shift in U-I collaboration factors across the periods is cyclical. Supplementary comparative studies, including further points in time, and better adapted to the study objective data set, might also contribute to better understanding the relationships under analysis. Moreover, the existing policy instrument related data applied in this study is rather generic. Further studies of more specific economic development policy instruments would be of major relevance to providing decision-makers with a better understanding of the effectiveness of specific instruments for stimulating U-I collaboration and their impact on economic growth.

Furthermore, our study is limited to quantitatively studying the problem and amounts to just a first step in providing relevant pointers on improving U-I collaboration policies depending on specific socioeconomic contexts. The findings require further development and substantiation by a mixed approach or qualitative research undertaking comparative analysis of the impacts of specific macro-level measures in relation to the specific characteristics of economies. Further studies should strive to clearly understand how specific NIS structures, differences in culture, knowledge and resources impact on the 
effectiveness of particular policy measures in countries across different levels of development and how policy makers in specific contexts should structure their measures for fostering U-I collaboration to optimise the benefits from the investments they make. Additionally, our study does not reach beyond the national economy level. As the regional context for innovation and policymaking is increasing, some effects may be disguised by the high-level aggregation. Therefore, studies based on regional level analysis within an international perspective and comparing their results could deeply contribute to a better analytical understanding of the policy influences on U-I collaboration.

\section{Appendices}

TABLE 1 Sample summary

2014-2015

\begin{tabular}{lll} 
Developed & Developing without LDC & LDC \\
\hline Australia & United Arab Emirates & Angola \\
Austria & Argentina & Armenia \\
Belgium & Bahrain & Azerbaijan \\
Bulgaria & Brazil & Burundi \\
Canada & Barbados & Burkina Faso \\
Switzerland & Chile & Bangladesh \\
Cyprus & China & Bolivia \\
Czech Republic & Cameroon & Bhutan \\
Germany & Colombia & Botswana \\
Denmark & Cabo Verde & Ethiopia \\
Spain & Costa Rica & Guinea \\
Estonia & Dominican Republic & Gambia, The \\
Finland & Algeria & Haiti \\
France & Egypt, Arab Rep. & Kazakhstan \\
United Kingdom & Gabon & Cambodia \\
Greece & Ghana & Lesotho \\
Croatia & Guatemala & Madagascar \\
Hungary & Guyana & Mali \\
Ireland & Hong Kong sar, China & Myanmar \\
Iceland & Honduras & Mongolia \\
Israel & Indonesia & Mozambique
\end{tabular}


TABLE 1 Sample summary (cont.)

2014-2015

\begin{tabular}{|c|c|c|}
\hline Developed & Developing without LDC & LDC \\
\hline Italy & India & Mauritania \\
\hline Japan & Iran, Islamic Rep. & Malawi \\
\hline Lithuania & Jamaica & Nepal \\
\hline Luxembourg & Jordan & Paraguay \\
\hline Latvia & Kenya & Rwanda \\
\hline Malta & Korea, Rep. & Senegal \\
\hline Netherlands & Kuwait & Sierra Leone \\
\hline Norway & Lebanon & Chad \\
\hline New Zealand & Libya & Tajikistan \\
\hline Poland & Sri Lanka & Timor-Leste \\
\hline Portugal & Morocco & Tanzania \\
\hline Romania & Mexico & Uganda \\
\hline Slovak Republic & Mauritius & Yemen, Rep. \\
\hline Slovenia & Malaysia & Zambia \\
\hline Sweden & Namibia & Zimbabwe \\
\hline \multirow[t]{19}{*}{ United States } & Nigeria & \\
\hline & Nicaragua & \\
\hline & Oman & \\
\hline & Pakistan & \\
\hline & Panama & \\
\hline & Peru & \\
\hline & Philippines & \\
\hline & Qatar & \\
\hline & Saudi Arabia & \\
\hline & Singapore & \\
\hline & El Salvador & \\
\hline & Thailand & \\
\hline & Trinidad and Tobago & \\
\hline & Tunisia & \\
\hline & Turkey & \\
\hline & Uruguay & \\
\hline & Venezuela, R в & \\
\hline & Vietnam & \\
\hline & South Africa & \\
\hline
\end{tabular}


TABLE 1 Sample summary (cont.)

2017-2018

Developed

Developing without LDC

LDC

Australia

Austria

Belgium

Bulgaria

Canada

Switzerland

Cyprus

Czech Republic

Germany

Denmark

Spain

Estonia

Finland

France

United Kingdom

Greece

Croatia

Hungary

Ireland

Iceland

Israel

Italy

Japan

Lithuania

Luxembourg

Latvia

Malta

Netherlands

Norway

New Zealand

Poland

Portugal

Romania
United Arab Emirates

Argentina

Bahrain

Brazil

Brunei Darussalam

Chile

China

Cameroon

Colombia

Cabo Verde

Costa Rica

Dominican Republic

Algeria

Ecuador

Egypt, Arab Rep.

Ghana

Guatemala

Hong Kong SAR, China

Honduras

Indonesia

India

Iran, Islamic Rep.

Jamaica

Jordan

Kenya

Korea, Rep.

Kuwait

Lebanon

Sri Lanka

Morocco

Mexico

Mauritius

Malaysia
Armenia

Azerbaijan

Burundi

Benin

Bangladesh

Bhutan

Botswana

Congo, Dem.

Rep.

Ethiopia

Guinea

Gambia, The

Haiti

Kazakhstan

Cambodia

Liberia

Lesotho

Madagascar

Mali

Mongolia

Mozambique

Mauritania

Malawi

Nepal

Paraguay

Rwanda

Senegal

Sierra Leone

Chad

Tajikistan

Tanzania

Uganda

Yemen, Rep.

Zambia 
TABLE 1 Sample summary (cont.)

2017-2018

\begin{tabular}{lll} 
Developed & Developing without LDC & LDC \\
\hline Slovak Republic & Namibia & Zimbabwe \\
Slovenia & Nigeria & \\
Sweden & Nicaragua & \\
United States & Oman & Pakistan \\
& Panama & Peru \\
& Philippines \\
& Qatar \\
& Saudi Arabia \\
& Singapore \\
& El Salvador \\
& Thailand \\
& Trinidad and Tobago \\
& Tunisia \\
& Turkey \\
Uruguay & Venezuela, RB \\
Vietnam \\
South Africa \\
\end{tabular}




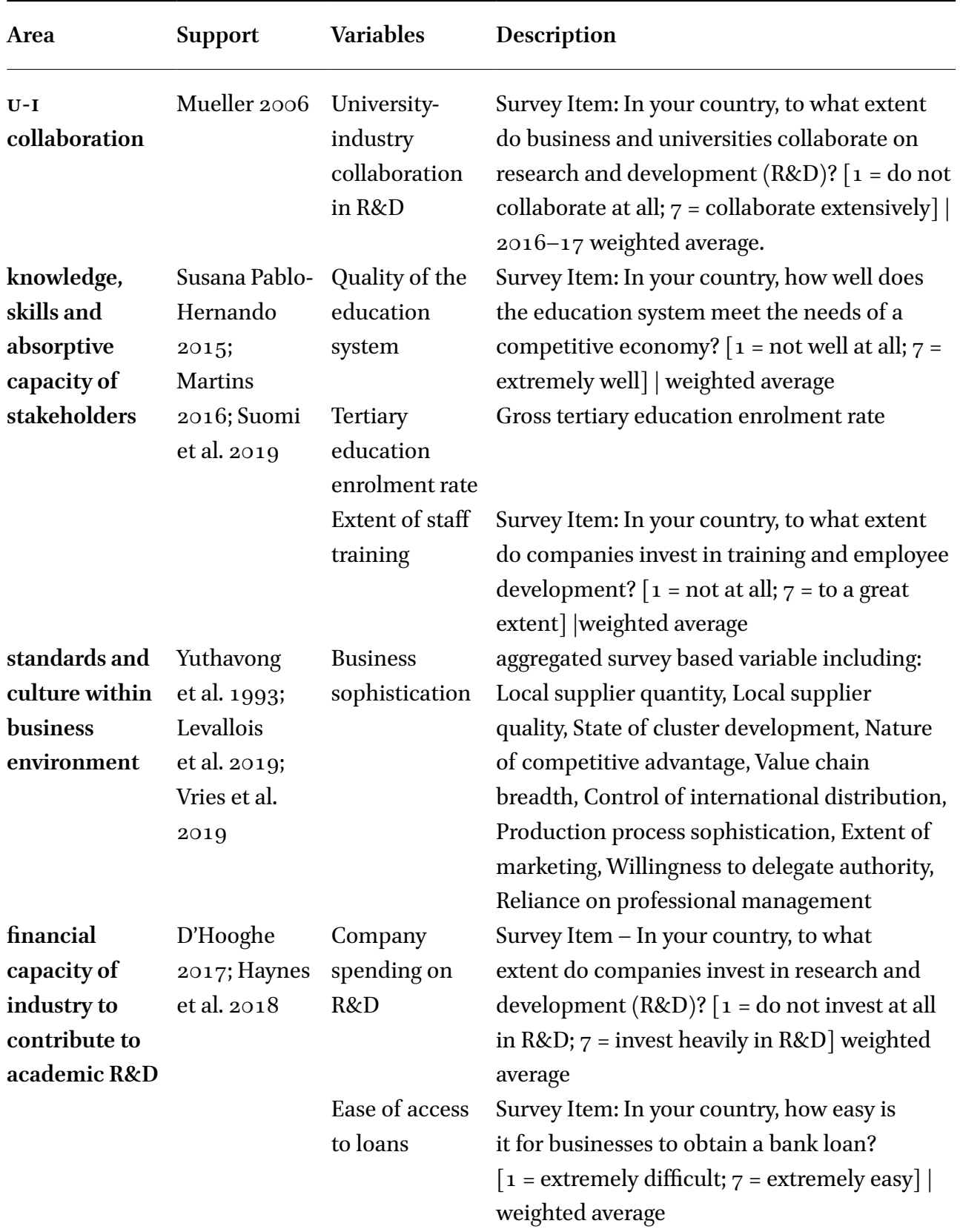


TABLE 8 List of variables used in the U-I collaboration models (cont.)

\begin{tabular}{|c|c|c|c|}
\hline Area & Support & Variables & Description \\
\hline \multirow{3}{*}{$\begin{array}{l}\text { accessibility } \\
\text { of quality } \\
\text { research }\end{array}$} & \multirow{3}{*}{$\begin{array}{l}\text { D’Hooghe } \\
2017 ; \text { Kim } \\
\text { and Jang } \\
2019\end{array}$} & $\begin{array}{l}\text { Effect of } \\
\text { taxation on } \\
\text { incentives to } \\
\text { invest } \\
\text { Availability } \\
\text { of financial } \\
\text { services }\end{array}$ & $\begin{array}{l}\text { Survey Item: In your country, to what extent } \\
\text { do taxes reduce the incentive to invest? [ } 1= \\
\text { to a great extent; } 7 \text { = not at all] | weighted } \\
\text { average } \\
\text { Survey Item: In your country, to what } \\
\text { extent does the financial sector provide the } \\
\text { products and services that meet the needs } \\
\text { of businesses? [ } 1 \text { = not at all; } 7 \text { = to a great } \\
\text { extent] }\end{array}$ \\
\hline & & $\begin{array}{l}\text { Quality of } \\
\text { scientific } \\
\text { research } \\
\text { institutions }\end{array}$ & $\begin{array}{l}\text { Survey Item: In your country, how do you } \\
\text { assess the quality of scientific research } \\
\text { institutions? [ } 1 \text { = extremely poor - among } \\
\text { the worst in the world; } 7 \text { = extremely good - } \\
\text { among the best in the world] |weighted } \\
\text { average }\end{array}$ \\
\hline & & $\begin{array}{l}\text { Availability of } \\
\text { scientists and } \\
\text { engineers }\end{array}$ & $\begin{array}{l}\text { Survey Item: In your country, to what extent } \\
\text { are scientists and engineers available? [ } 1=\text { not } \\
\text { available at all; } 7 \text { = widely available] } \mid \text { weighted } \\
\text { average }\end{array}$ \\
\hline \multirow[t]{4}{*}{$\begin{array}{l}\text { existence of } \\
\text { innovation } \\
\text { system } \\
\text { support } \\
\text { measures }\end{array}$} & $\begin{array}{l}\text { van den } \\
\text { Bergha and } \\
\text { Guild 2008; } \\
\text { D’Hooghe } \\
\text { 2017; Hassen } \\
\text { 2018; Kim }\end{array}$ & $\begin{array}{l}\text { Quality } \\
\text { of overall } \\
\text { infrastructure }\end{array}$ & $\begin{array}{l}\text { Survey Item: How do you assess the general } \\
\text { state of infrastructure (e.g., transport, } \\
\text { communications, and energy) in your } \\
\text { country? [ } 1 \text { = extremely underdeveloped - } \\
\text { among the worst in the world; } 7 \text { = extensive } \\
\text { and efficient - among the best in the world] | }\end{array}$ \\
\hline & $\begin{array}{l}\text { and Jang } \\
2019\end{array}$ & $\begin{array}{l}\text { Intellectual } \\
\text { property }\end{array}$ & $\begin{array}{l}\text { Survey Item: In your country, to what extent is } \\
\text { intellectual property protected? [ } 1=\text { not at all; }\end{array}$ \\
\hline & & protection & $7=$ to $\mathrm{a}$ great extent $] \mid$ weighted average \\
\hline & & $\begin{array}{l}\text { Efficiency } \\
\text { of legal } \\
\text { framework } \\
\text { in settling } \\
\text { disputes }\end{array}$ & $\begin{array}{l}\text { Survey Item: In your country, how efficient are } \\
\text { the legal and judicial systems for companies } \\
\text { in settling disputes? [ } 1 \text { = extremely inefficient; } \\
7 \text { = extremely efficient] | weighted average }\end{array}$ \\
\hline
\end{tabular}




\begin{tabular}{|c|c|c|c|}
\hline Area & Support & Variables & Description \\
\hline $\begin{array}{l}\text { orientation of } \\
\text { government } \\
\text { toward } \\
\text { creating } \\
\text { innovation- } \\
\text { enabling } \\
\text { culture }\end{array}$ & $\begin{array}{l}\text { Kim and Jang } \\
2019 ; \text { Suomi } \\
\text { et al. } 2019\end{array}$ & $\begin{array}{l}\text { Efficiency } \\
\text { of legal } \\
\text { framework in } \\
\text { challenging } \\
\text { regulations } \\
\text { Transparency } \\
\text { of government } \\
\text { policymaking }\end{array}$ & $\begin{array}{l}\text { Survey Item: In your country, how easy is it for } \\
\text { private businesses to challenge government } \\
\text { actions and/or regulations through the legal } \\
\text { system? [ } 1 \text { = extremely difficult; } 7 \text { = extremely } \\
\text { easy] | weighted average } \\
\text { Survey Item: In your country, how easy } \\
\text { is it for companies to obtain information } \\
\text { about changes in government policies and } \\
\text { regulations affecting their activities? [ } 1 \text { = } \\
\text { extremely difficult; } 7 \text { = extremely easy] | } \\
\text { weighted average } \\
\text { Survey Item: In your country, how burdensome } \\
\text { is it for companies to comply with public } \\
\text { administration's requirements (e.g., permits, } \\
\text { regulations, reporting)? [ } 1 \text { = extremely } \\
\text { burdensome; } 7 \text { = not burdensome at all] }\end{array}$ \\
\hline
\end{tabular}

The variables deployed resulted from Executive Opinion Survey conducted by the World Bank. For the 2017/2018 data, the process involved 14375 respondents, with a total of 12775 responses included in the study and 14 ooo in 2014/2015. In the survey, respondents evaluate specific aspects of their environment on a 7 point scale ( 1 - the worst possible situation; 7 - the best possible situation)

\section{References}

Alfaro L, Chanda A, Kalemli-ozcan S and Sayek S (2004) FDI and economic growth: the role of local financial markets. Journal of International Economics 64(1): 89-112.

Alshehri A, Gutub SA, Ebrahim MA-B, Shafeek H, Soliman MF and Abdel-Aziz MH (2016) Integration between industry and university: case study, Faculty of Engineering at Rabigh, Saudi Arabia. Education for Chemical Engineers 14: 24-34.

Amaral M, Ferreira A and Teodoro P (2011) Building an entrepreneurial university in Brazil: the role and potential of university-industry linkages in promoting regional economic development. Industry and Higher Education 25(5): 383-395.

Ambroziak E, Starosta P and Sztaudynger JJ (2016) Zaufanie, skłonność do pomocy i uczciwość a wzrost gospodarczy w Europie. Ekonomista 6: 647-673.

Ankrah S and Omar AT (2015) Universities-industry collaboration: a systematic review. Scandinavian Journal of Management 31(3): 387-408. 
BCG (2012) Speed to Win. How Fast-Moving Consumer-Goods Companies Use Speed as a Competitive Weapon. Boston: The Boston Consulting Group.

Berman EM (1990) The economic impact of industry-funded university R\&D. Research Policy 19(4): 349-355.

BMWfW (2015) Open Innovation Strategy for Austria, Goals, Measures \& Methods. Federal Ministry of Science, Research and Economy (BMWFW).

Cassanelli AN, Fernandez-Sanchez G and Guiridlian MC (2017) Principal researcher and project manager: who should drive R\&D projects? R\&D Management 47(2): 277-287.

Chen F, Wu C, Yang W and Zhang W (2013) S\&T collaboration platform for Higher Education institutions and industry: a case study of Wenzhou, China. Inzinerine Ekonomika-Engineering Economics 24(5): 424-436.

Coccia M (2009) Research performance and bureaucracy within public research labs. Scientometrics 79: 93-107.

Cooke P (2002) Biotechnology clusters as regional, sectoral innovation systems. International Regional Science Review 25(1): 8-37.

Cowan R and Zinovyeva N (2013) University effects on regional innovation. Research Policy 42(3): 788-8oo.

D'Hooghe T (2017) Transparent collaboration between industry and academia can serve unmet patient need and contribute to reproductive public health. Human Reproduction 32(8): 1549-1555.

Etzkowitz H and Leydesdorff L (2000) The dynamics of innovation: from national systems and "mode 2 " to a triple helix of university-industry-government relations. Research Policy 29(2): 109-123.

EU (2020) University-Industry Collaboration. A Policy Brief from the Policy Learning Platform on Research and Innovation. Interreg Europe.

Fischer S (1993) The role of macroeconomic factors in growth. Journal of Monetary Economics 32(3): 485-512.

Freeman C (1982) Technological infrastructure and international competitiveness. Draft Paper Submitted to the OECD Ad hoc Group on Science, Technology and Competitiveness.

Freeman C (1987) Technology Policy and Economic Performance: Lessons from Japan. London: Pinter.

Freitas IMB and Tunzelmann N (2008) Mapping public support for innovation: a comparison of policy alignment in the UK and France. Research Policy 37(9): 1446-1464.

Furman JL, Porter ME and Stern S (2002) The determinants of national innovative capacity. Research Policy 31: 899-933.

Galán-Muros V and Plewa C (2016) What drives and inhibits university-business cooperation in Europe? A comprehensive assessment. R\&D Management, 46(2): $369-382$. 
Gann DM, Wang J and Hawkins R (1998) Do regulations encourage innovation? The case of energy efficiency in housing. Building Research \& Information 26(5): 28o-296.

Gera R (2012) Bridging the gap in knowledge transfer between academia and practitioners. International Journal of Educational Management 26(3): 252-273.

Gonzalez-Pernia J and Pena-Legazkue I (2015) Export-oriented entrepreneurship and regional economic growth. Small Business Economics 45(3): 505-522.

Hair J, Black W, Babin B and Anderson R (2010) Multivariate Data Analysis. Seventh edition. Upper Saddle River, NJ: Prentice-Hall.

Hassen TB (2018) Knowledge and innovation in the Lebanese software industry. Cogent Social Sciences 4(1): 1-17.

Havas A (2015) Types of knowledge and diversity of business-academia collaborations: implications for measurement and policy. Triple Helix 2(1):1-26.

Hayden M, Petrova C, Margarita K and Wutti D (2018) Direct associations of the terminology of knowledge transfer - differences between the Social Sciences and Humanities (SSH) and other scientific disciplines. Trames Journal of the Humanities and Social Sciences 22(3): 239-256.

Hou B, Hong J and Shi X (2021) Efficiency of university-industry collaboration and its determinants: evidence from Chinese leading universities. Industry and Innovation 28(4): $45^{6-485}$.

Howarth C and Monasterolo I (2016) Understanding barriers to decision making in the UK energy-food-water nexus: the added value of interdisciplinary approaches. Environmental Science \& Policy 61: 53-6o.

Kim L and Jang DH (2021) Culturing atmosphere for spontaneous innovation: academic action and triple-helix dynamics in South Korea. Higher Education Policy 34: 429-455.

Langford CH, Langford MW and Douglas Burch R (1997) The "well-stirred reactor": evolution of industry-government-university relations in Canada. Science and Public Policy 24(1): 21-27.

Lee SH and Yoo T (2007) Government policy and trajectories of radical innovation in Dirigiste states: a comparative analysis of national innovation systems in France and Korea. Technology Analysis and Strategic Management 19(4): 451-470.

Levallois C, Smidts A and Wouters P (2021) The emergence of neuromarketing investigated though online public communications (2002-2008). Business History 63(3): $443-466$.

Leydesdorff L, Park HW and Lengyel B (2014) A routine for measuring synergy in university-industry-government relations: mutual information as a triple-helix and quadruple-helix indicator. Scientometrics 99(1): 27-35.

Lundvall B (2007) National innovation systems - analytical concept and development tool. Industry and Innovation 14(1): 95-119. 
Maar B (2012) Key Performance Indicators (KPI): The 75 Measures Every Manager Needs to Know. London: Pearson.

Macleod G, McFarlane B and Davis CH (1997) The knowledge economy and the social economy: university support for community enterprise development as a strategy for economic regeneration in distressed regions in Canada and Mexico. International Journal of Social Economics 24(11): 1302-1324.

Mark M, Jensen RL and Norn MT (2014) Estimating the economic effects of universityindustry collaboration. International Journal of Technology Transfer and Commercialisation 13(1/2): 80-106.

Martins JT (2016) Relational capabilities to leverage new knowledge: managing directors' perceptions in UK and Portugal old industrial regions. Learning Organization 23(6): 398-414.

Mowery DC and Sampat BN (2004) The Bayh-Dole Act of 1980 and universityindustry technology transfer: a model for other OECD governments? The Journal of Technology Transfer 30(1/2): 115-127.

Mueller P (2006) Exploring the knowledge filter: how entrepreneurship and universityindustry relationships drive economic growth. Research Policy 35: 1499-1508.

Nelson RR (1990) Capitalism as an engine of progress. Research Policy 19(3): 193-214.

Nsanzumuhire SU and Groot W (2020) Context perspective on university-industry collaboration processes: a systematic review of literature. Journal of Cleaner Production 258: 120861.

oECD (2019) University-Industry Collaboration: New Evidence and Policy Options. Paris: oECD. Available at: https://doi.org/10.1787/egcre648-en.

Pablo-Hernando S (2015) Transferring knowledge: PhD holders employed in Spanish technology centres. International Journal of Technology Management 68(3/4): 228-254.

Peng S, Ferreira FAF and Zheng H (2017) A university-industry cooperation model for small and medium enterprises: the case of Chengdu KEDA Optoelectronic Technology Ltd. International Journal of Learning and Change 9(1): 29-45.

Petroni G, Venturini K and Verbano C (2012) Open innovation and new issues in R\&D organization and personnel management. International Journal Of Human Resource Management 23(1): 147-173.

Plewa C, Korff N, Baaken T and Macpherson G (2013) University-industry linkage evolution: an empirical investigation of relational success factors. $R \& D$ Management 43(4): $365-380$.

Plewa C, Korff N, Johnson C, Macpherson G, Baaken T and Rampersad GC (2013) The evolution of university-industry linkages - A framework. Journal of Engineering and Technology Management 30(1): 21-44. 
Rad MF, Seyedesfahani MM and Jalilvand MR (2015) An effective collaboration model between industry and university based on the theory of self organization: a system dynamics model. Journal of Science and Technology Policy Management 6(1): 2-24.

Ranga LM, Miedema J and Jorna R (2008) Enhancing the innovative capacity of small firms through triple helix interactions: challenges and opportunities. Technology Analysis and Strategic Management 20(6): 697-716.

Romer PM (1990) Endogenous technological change. Journal of Political Economy 98(5): 71-102.

Rostow WW (1962) The Stages of Economic Growth. London: Cambridge University Press.

Runiewicz-Wardyn M (2014) Geographic and technological pattern of knowledge spillovers as evidenced by technical universities in CEE countries. Engineering Economics 25(4): 466-473.

Salem A-A and Amjed A-F (2008) An innovative model for university industry partnership. International Journal of Innovation and Learning 5(5): 512-532.

Sandberg J, Holmström J, Napier N and Levén P (2015) Balancing diversity in innovation networks: trading zones in university-industry R\&D collaboration. European Journal of Innovation Management 18(1): 44-69.

Simionescu M, Lazányi K, Sopková G, Dobeš K and Balcerzak AP (2017) Determinants of economic growth in $\mathrm{V}_{4}$ countries and Romania. Journal of Competitiveness 9(1): $103-116$.

Suomi K, Kuoppakangas P and Stenvall J (2019) Revisiting "the shotgun wedding of industry and academia" - empirical evidence from Finland. International Review on Public and Nonprofit Marketing 16(1): 81-102.

Teller R and Validova AF (2015) Innovation management in the light of universityindustry collaboration in post-socialist countries. Procedia Economics and Finance, 24: 691-700.

Valliere D and Peterson R (2009) Entrepreneurship and economic growth: evidence from emerging and developed countries. Entrepreneurship and Regional Development 21(5/6): 459-48o.

van den Berghe L and Guild PD (2008) The strategic value of new university technology and its impact on exclusivity of licensing transactions: An empirical study. Journal of Technology Transfer, 33(1), 91-103.

van Dyke J (2017) Innovation Speed to Market Report. How Financial Sector Firms Manage Innovation Projects To Meet Timelines and Customer Needs. CI\&T. Futurion. Available at: https://www.icba.org/docs/default-source/icba/solutions-documents/ knowledge-vault/innovation-speed-to-market-report.

van Norman GA (2016) Drugs, devices, and the FDA: part 2: an overview of approval processes: FDA approval of medical devices. JACC: Basic to Translational Science 1(4): 277-287. 
van Stel A, Carree M and Thurik R (2005) The effect of entrepreneurial activity on national economic growth. Small Business Economics 24(3): 311-321.

Vanhaverbeke W (2017) Managing Open Innovation in SMEs. Cambridge: Cambridge University Press.

Vries E, Dolfsma WA and Windt HJ (2019) Knowledge transfer in university-industry research partnerships: a review. The Journal of Technology Transfer 44(4): 1236-1255.

Watkins A, Papaioannou T, Mugwagwa J and Kale D (2015) National innovation systems and the intermediary role of industry associations in building institutional capacities for innovation in developing countries: a critical review of the literature. Research Policy 44(8): 407-1418.

Welsh, R., Glenna, L., Lacy, W., \& Biscotti, D. (2008). Close enough but not too far: Assessing the effects of university-industry research relationships and the rise of academic capitalism. Research Policy, 37(10), 1854-1864.

Welfe A (2008) Ekonometria. Metody i ich zastosowanie. Warszawa: Polskie Wydawnici two Ekonomiczne SA.

Wonglimpiyarat J and Khaemasunun P (2015) China's innovation financing system: triple helix policy perspectives. Triple Helix 2(1): 1-18.

Wong PX, Ho YP and Autio E (2005) Entrepreneurship, innovation and economic growth: Evidence from GEM data. Small Business Economics 24(3): $335^{-35}$.

Yuthavong Y, Phornsadja K, Chungcharoen A, Eisemon TO and Davis CH (1993) Communication strategies in tissue culture and seed research in Thailand. Scientometrics 28(1): 41-6o. 